\title{
AMAKUDARI AND JAPANESE LAW
}

\author{
Colin P.A. Jones*
}

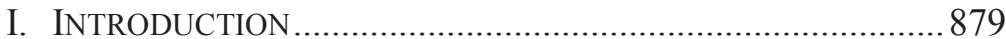

II. THE INSTITUTIONAL BACKGROUND................................... 882

III. EXAMPLES OF AMAKUDARI IN PRACTICE .......................... 888

A.Private Sector Amakudari and Corporate Governance 888

B. Home-grown Amakudari - Foundations and Other Special Entities.

C. Jigyō Shiwake - A Window Into the World of Amakudari Foundations

IV. HOW AMAKUDARI FOUNDATIONS MAY

SHAPE THE LAW

V.AMAKUDARI AND THE PRIVATE-SECTOR

LEGAL PROFESSIONS

A. Law schools and the Artificial "Hōsō Population Problem"

B. Into the Jungle: the Taxonomy of Japanese Legal Professions

C. Private Sector Legal Professions as a Retirement Plan.

D. The Legal Professions as a Source of Indirect Amakudari

E. New Legal Professions - the More the Merrier?.......938

F. Amakudari and the Law; Another Look at Public Notaries

G. Government Legal Professions and More Amakudari 945

VI. CONCLUDING REMARKS - AMAKUDARI AS A STRUCTURAL PROBLEM IN THE LEGAL SYSTEM AND BEYOND 954

\section{INTRODUCTION}

Amakudari - literally "descent from heaven" - is a Japanese term used to refer to the practice of government officials retiring into industries and institutions, often those that they have formerly been involved in regulating. It is a practice that is 
sometimes described as an endemic feature of the Japanese "system." One study goes so far as to describe amakudari as the "hidden fabric" of the country's economy. ${ }^{2}$ It is also a subject that has been the focus of a prolonged political battle between elected politicians seeking to end this form of institutional nepotism (or at least trying to appear to be fighting the bureaucrats for the benefit of voters), and bureaucrats preserving various techniques that result in the practice taking on new forms.

Despite being a commonly identified feature of Japan's political economy, formal research specifically on the subject of amakudari within Japan is surprisingly sparse, according to one Japanese scholar. ${ }^{3}$ Moreover, the subject tends to be discussed in terms of bureaucrats using their authority to spend tax money as a means of securing post-retirement sinecures, i.e., the economic impact of amakudari. ${ }^{4}$ Yet the exercise of authority involved in implementing amakudari generally requires a legal basis. However, the role and impact of amakudari on the functioning of the Japanese legal system and the way in which legal institutions have developed does not appear to have been given much consideration. Amakudari is frequently accomplished through

* Professor, Doshisha University Law School LL.M. Tohoku University, J.D. and LL.M. Duke University School of Law. All translations of Japanese source materials have been provided by the author unless otherwise noted.

See, e.g., Brian WoOdAll, JAPAN UNDER CONSTRUCTION (1996), 40-41, 68-78, 125-26, 130-39; Chalmers Johnson, The Reemployment of Retired Government Bureaucrats in Japanese Big Business, JAPAN: WHO Governs? (1995), Chalmers Johnson, On Official Bureaucracy id., at 133-138, 141-56; Karl VAN Wolferen, The Enigma of JaPANESE Power (1989), 113$19,122-24$.

2. See generally RiCHARD COLIGNON \& CHIKAKO USUI, AMAKUDARI: THE HidDEN FABRIC OF JAPAN's ECONOMY (2003) (describing the role of Amukadari in the Japanese economy).

3. Masashi Nakano, Amakudari no kenkyū [The Study of AMAKUDARI] 24 (2009) (Japan).

4. See, e.g., WoODALl, supra note 1 (describing Japanese Ministry of Construction). KAZUhito YAMASHITA, NōKYō NO INBŌ [THE AgRICUlturAL COOPERATIVE CONSPIRACY] 158-59 (2011) (Japan). 
law and regulations, which are often drafted by the same bureaucrats who benefit from it. Amakudari should thus be an identifiable feature of the legal system as well as the economy. Accordingly, this article will seek to introduce some of the ways in which amakudari may play a largely hidden role in Japanese law and legal institutions.

This article will not delve deeply into the causes, utility, merits or comparative aspects of amakudari, a subject that has been looked at by other scholars in any case. ${ }^{5}$ Furthermore, although there are more specific terms for particular modalities, this article will only use the term amakudari as a general term that refers to all of them. ${ }^{6}$ The author believes that such usage is consistent with amakudari as it is used in common parlance in Japan, as a reference to all forms of post-retirement employment by public employees in situations where the relevant government agency is likely able to directly or indirectly use its position to facilitate or structure such employment on preferential terms. While this article will not seek to consider or develop formal definitions of amakudari, in passing the author would offer "structured post-retirement employment for public servants" as one possible candidate.

Additionally, although most literature on the subject focuses primarily on amakudari by elite bureaucrats from the national government, this article will use the term generally to refer to structured post-retirement employment at all levels of the

5. See, e.g., Colignon \& UsUI, supra note 2, at 38-43 (giving an overview of the various theories of the causes and potential merits of amakudari).

6. See, e.g., Colignon \& Usui distinguish between amakudari ("the movement from ministry or agency to a private business"), yokosuberi (bureaucrats moving "into public corporations or special legal entities"), wataridori ("serial retirements in the public and/or private sector") and seikaitensin (bureaucrats moving "into the political world, chiefly by becoming candidates for election to the Diet"). CoLIGNON \& UsUI, supra note 2, at 11. This article essentially uses amakudari as a blanket descriptor for the first three types of career transitions. Nakano also notes a wide variety of definitions of amakudari exist. NAKANO, supra note 3, at 23-33. 
national public service. ${ }^{7}$ As will be shown, some of Japan's legal professions may function as a form of amakudari for a wide range of ex-bureaucrats below the high-fliers who garner most of the attention (and criticism). In this light the description of amakudari as "a kind of colonization of the public and private sectors by the ministries" ${ }^{8}$ seems particularly apt; colonial systems involved both high level administrators and low level functionaries, all of whom enjoyed a privileged status compared to the much greater colonized population.

After a general discussion of the amakudari, this article will discuss how it may affect the Japanese legal system in four principle contexts: (1) the private sector, (2) quasi-private foundations and other institutions, (3) the private sector legal professions and (4) governmental legal professions.

\section{THE INSTITUTIONAL BACKGROUND}

A number of features of Japanese bureaucracies and their role in the legal system need to be discussed in order to understand how amakudari may be a factor in it. First, most categories of national public servants are subject to mandatory retirement at a specific age. For most that age has long been $60 .{ }^{9}$ Judges,

7. Japan has a two-tiered public service, with local public servants being subject to rules based on the national standard, subject to such modifications as are applied by local government ordinances. Chihōkōmuinhō [Local Public Service Act], Law no. 261 of 1950, Art. 82-2 (Japan). Amakudari by local government officials does occur but will not be discussed.

8. Colignon \& Usui, supra note 2, at 51.

9. Kokkakōmuinhō [National Public Service Act], Law No. 120 of 1947, arts. 81-2(2) (Japan), English translation available at Japanese Law Translation, MINISTRY OF JUST., (Apr. 1, 2009) http://www.japaneselawtranslation.go.jp/law/detail/?id=2141\&vm=04\&re=02 . The website of the Ministry of Internal Affairs and Communications (MIC), which has partial jurisdiction over the public service, contains a useful list of retirement age of national government workers, giving 60 as the retirement age for most. Exceptions include Vice Ministers (typically the top bureaucrat in each Minister) who retire at 62, security guards, consular employees, and certain other special categories who retire at 63 , and heads of national research 
however, have a higher age of 65 , or 70 for Supreme Court justices and summary court judges. ${ }^{10}$ Under the National Public Service Act, non-judicial court employees of various types are designated as "special service" public servants. ${ }^{11}$ For the most part, they are subject to the same mandatory retirement age of 60 as other national public servants (subject again to the recentlyintroduced system of reemployment in non-managerial positions until the age of 65). ${ }^{12}$ As is discussed later, the court system also employs a variety of specialized public servants - some on a part-time basis - who are subject to a higher mandatory

institutions and doctors at national hospitals who retire at 65. Retirement Ages, MinisTRY OF INTERNAL AFF. \& COMM., http://www.soumu.go.jp/main_sosiki /jinji/jinji_04d.html (Japan) (last visited Mar. 1, 2014). Because the payment commencement date for public pensions is being transitioned from 60 to 65, there is now a program enabling national public servants to apply to be reemployed during the period in which they would otherwise have no income. Public employees re-employed in this manner essentially take a pay cut, cease to hold managerial positions and are ineligible for promotions. See Public Employee Retirement, NAT'L PERS. AuTH. (NPA), http://www.jinji.go.jp/ shougai-so-go-joho/work/ (Japan) (last visited Mar. 1, 2014); Public Employee Pensions, NPA, http://www.jinji.go.jp/shougai-so-go-joho/work/pay.html (last visited Mar. 1, 2014); Public Employee Allowance, NPA, http://www.jinji.go.jp/shougai-so-go-joho/work/allowance.html (Japan) (giving program descriptions) (last visited Mar. 1, 2014)._The descriptions for the age at which public pension payments commence is also described online. Ages for Pension Eligibility, JAPAN PENSION SERV., http://www.nenkin.go.jp/n/www /yougo/detail.jsp?id=125 (Japan) (last visited Mar. 1, 2014); Overview of the Public Pension System, Fed'n Nat'l Pub. Service Personnel Mutual Aid Ass'NS., http://www.kkr.or.jp/nenkin/seido/aramashi/index.html (last visited Mar. 1, 2014).

10. Saibanshōhō [Courts Act], Law No. 59 of 1947, art. 50., English

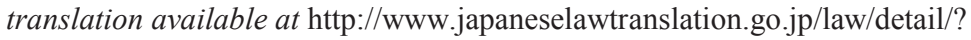
$\mathrm{re}=01 \& \mathrm{dn}=1 \& \mathrm{x}=0 \& \mathrm{y}=0 \& \mathrm{co}=1 \& \mathrm{yo}=\& \mathrm{gn}=\& \mathrm{sy}=\& \mathrm{ht}=\& \mathrm{no}=\& \mathrm{bu}=\& \mathrm{ta}=\& \mathrm{ky}=\%$ E8\%A3\%81\%E5\%88\%A4\%E6\%89\%80\%E6\%B3\%95\&page=7 (Japan) (last visited Mar. 1, 2014).

11. Kokkakōmuinhō [National Public Service Act], Law No. 120 of 1947, art. 2(3)(xiii) (Japan), English translation available at Japanese Law Translation, MiNISTRY OF JUST., (Apr. 1, 2009), http://www.japaneselaw translation.go.jp/law/detail $/$ ft $=1 \& \mathrm{re}=01 \& \mathrm{dn}=1 \& \mathrm{x}=0 \& \mathrm{y}=0 \& \mathrm{co}=01 \& \mathrm{ky}=\% \mathrm{E} 5$ \%9B\%BD $\%$ E5\%AE\%B6\%E5\%85\%AC\%E5\%8B\%99\%E5\%93\%A1\%E6\%B3 $\% 95 \&$ page $=5$.

12. Id. 
retirement age, typically $70 .{ }^{13}$ Finally, it should be noted that prosecutors must retire at 63, except for the Supreme Prosecutor for whom the age of retirement is set at $65 .{ }^{14}$ The average Japanese person can now expect to live until around the age of 80 if not beyond. ${ }^{15}$ The mandatory retirement age thus leaves career public servants with the prospect of funding fifteen to twenty more years of life, ideally with more than just their pension.

Another feature of the national public service is that it is based on "lifetime employment" in the classical Japanese model. The typical career path for a bureaucrat would start with a university student passing one of the national public service exams and joining one of the ministries, agencies or other central government administrative institutions (for simplicity this article will refer simply to them collectively as "ministries") after graduation. ${ }^{16}$ There are a variety of categories of national public

13. Examples would be court enforcement officers (shikkōkan) and family court mediators (chōteiin).

14. Kensatuchōhō [Public Prosecutors Office Act], Law No. 61 of 1947, art. 22 (Japan). Note that although despite being subordinate to the Ministry of Justice, it is widely acknowledged that prosecutors actually control the Ministry. This can readily ascertained by the fact that at any given time most bureau chiefs within the Ministry are from the prosecutorial service. As a result, unlike most other ministries in which the Vice Minister is the top career official, in the Ministry of Justice (MOJ) it is the Supreme Prosecutor. As described by former prosecutor and Minister of Justice Toshio Ogawa, "In the Ministry of Justice, most top leadership posts starting with the vice minister and chief cabinet secretary are occupied by prosecutors. And the top prosecutorial job is that of supreme prosecutor. Unlike other ministries and agencies, the vice minister is merely another post on the way to becoming Supreme Prosecutor. Most personnel decisions are led by the Supreme Prosecutor." Toshio Ogawa, SHIKIKEN HATSUdō [EXERcise of THE DiRECTIVE POWER] 91 (2013) (Japan).

15. According to Ministry of Health, Welfare and Labor Statistics, as of 2009 the average life expectancies for Japanese men and women were 79.59 and 86.44, respectively. Life Expectancy, Ministry of HeAlth, Welfare, AND LABOR STATISTICS, http://www.mhlw.go.jp/toukei/saikin/hw/life/life09/01.html (last visited Feb. 28, 2014).

16. The career path of national public servants is common knowledge in Japan and it is described in whole or in part in numerous sources in both English and Japanese. See, e.g., WATARU OMORI, KANRYō SHISUTEMu [The 
servants, but it is common to distinguish between "career" and "non-career" tracks. This usage of "career" and "non-career" ("karia" and "nonkyaria" in Japanese) is confusing to English speakers because both refer to what we would consider "career bureaucrats" as distinct from political appointees. The difference in the Japanese context is that "career" bureaucrats are the elite: graduates of Tokyo University or other top schools who have passed the most difficult level of the national public service exam. They would be destined to become the elite within the ministry they would join and could be expected to advance to a certain level of managerial role within it. Non-career refers essentially to "everyone else," the much greater number of officials who handle the day-to-day affairs of the ministry and whose prospects of advancement to the top are limited by their non-elite status.

Bureaucrats joining a ministry rotate through a number of assignments, being advanced in rank and pay in lockstep with the other people who entered the ministry at the same time. For the elite "career" officials, these assignments may include being seconded to other ministries and time spent studying abroad. After a certain point however, the lockstep advancement ceases, and bureaucrats from the same entering class have to start competing for the limited number of posts at the top of the pyramid. ${ }^{17}$ At the top of the pyramid is the vice minister, the top career bureaucrat in each ministry. ${ }^{18}$

Bureaucrat System] 6-8, 101-109, 209-260 (2006) (Japan) (referencing peers of vice minister retiring at 102); see also KAZUMASA OKUBO, THE NATURE AND Role of the Civil Service in JAPANESE Government Decision-MAKING, PRI Discussion Paper Series (No.05A - 11), (July 2005), available at http://www.mof.go.jp/pri/research/discussion_paper/ron119.pdf; SHIGEAKI KOGA, KANRYō WO KOKUMIN NO TAME NI HATARAKASERU HŌ [HOW TO MAKE BUREAUCRATS WORK FOR THE PEOPLE] 56-92 (2011); VAN WOLFEREN, supra note 1, at 87, 109-158, WOODALL, supra note 1, at 51-80; see generally AKIRA NAKamura, Japan's Civil Service System NeEds Reform: Human RESOURCE DEVELOPMENT IN TRANSITION, available at http://unpan1.un.org/ intradoc/groups/public/documents/eropa/unpan014260.pdf

17. In one of his books on the Japanese bureaucracies Shigeaki Koga, a former high level METI official, notes the rigid lockstep nature of promotions 
As the upper tiers of the ministry hierarchy narrow, it becomes impossible to continue advancing everyone in lockstep. Furthermore, there has been an unspoken rule that members of the same class are nominally equal within the hierarchy, making it difficult for one to be in a position of telling another what to do. Public service jobs are heavily protected and it is virtually impossible to fire a bureaucrat before statutory retirement age. The easiest way to get rid of them may be to offer a job with the same benefits and a higher retirement age, either in the private sector or in a quasi-governmental entity the very existence of which may be due in part to the need to find jobs for retiring bureaucrats. ${ }^{19}$

but then goes on to state: "on the other hand there is fierce competition. This is because no matter how far one advances through senior system, there are not very many posts above the section chief [kachō] level. Ultimately, only one person from an entering class may become vice minister. So everyone aims at becoming a bureau chief and vice minister, while at the same time keeping an eye out for a good amakudari post in the event they fail. . . In addition, certain posts are important for becoming vice minister. At the Ministry of Finance it is the head of the Budget Bureau, at METI it is the head of the Economic and Trade Policy Bureau. Even though they may be the same age and salary may not vary much depending upon post, whether you become vice minister or not has a big impact on how you get treated in your subsequent amakudari life. So everyone fights vigorously for the posts that are on the route to becoming vice minister." KogA, supra note 16, at 76.

18. The Ministry of Justice arguably being an exception. Kokkakōmuinhō [National Public Service Act], Law No. 120 of 1947, art. 2(3)(xiii) (Japan), translated in Japanese Law Translation, MinISTRY OF JusT., (Apr. 1, 2009), http://www.japaneselawtranslation.go.jp/law/detail/?

$\mathrm{ft}=1 \& \mathrm{re}=01 \& \mathrm{dn}=1 \& \mathrm{x}=0 \& \mathrm{y}=0 \& \mathrm{co}=01 \& \mathrm{ky}=\% \mathrm{E} 5 \% 9 \mathrm{~B} \% \mathrm{BD} \% \mathrm{E} 5 \% \mathrm{AE} \% \mathrm{~B} 6 \% \mathrm{E}$

$5 \% 85 \% \mathrm{AC} \% \mathrm{E} 5 \% 8 \mathrm{~B} \% 99 \% \mathrm{E} 5 \% 93 \% \mathrm{~A} 1 \% \mathrm{E} 6 \% \mathrm{~B} 3 \% 95$ \&page $=5 ;$ see also COLIGNON \& UsUI supra note 2, at 7 (describing the pyramid structure and how it is a driving force in amakudari).

19. As described by Koga: "For those bureaucrats who fail at getting a post above that of section chief, even if they quit the protection of their status as a public servant effectively remains. METI bureaucrats who quit are still METI people, MOFA people who quit are still MOFA people. Wherever they end up through amakudari, they receive the same salary as a top official, at worst the same as a department head or bureau chief. Amakudari is a system that was borne from the seniority-based system in which people are advanced based on how long they have served." KogA, supra note 16, at 77. 
While most discussions of amakudari focus on elite bureaucrats, it should also be considered as a managerial problem for those same bureaucrats. Within the context of the so-called "lifetime" employment system, the fact that for most public officials it ended at the age of 60 (subject more recently to the possibility of re-employment on inferior terms until the age of 65) would be a personnel management issue for ministry leadership. There would thus be institutional incentives to procure post-retirement jobs not just for those approaching the top of the pyramid but "non-career" personnel as well. In fact, the statutory retirement age was less likely to be an issue for elite bureaucrats since many of them would have left government service before reaching that age. ${ }^{20}$

To the extent that amakudari involves the creation of a galaxy of "public interest" corporations and other quasi-public or ostensibly private institutions of questionable necessity, it is a feature of Japanese governance that has been estimated by one observer to have both cost Japanese taxpayers $¥ 12$ trillion and starved the market for legitimate non-profit organizations of funding and other resources. ${ }^{21}$

While there are numerous theories seeking to justify amakudari as a form of deferred compensation, a mechanism for establishing informal relations between regulators and the regulated or in other terms, and some have characterized amakudari as an unavoidable consequence of Japan's lifetime employment system, the point of this article is not to justify

20. Colignon \& Usui note that "the usual retirement age for the vice minister is slightly over fifty," which seems low but if true would mean that all others in his entering class would have to retire at roughly the same age or earlier. COLIGNON \& UsUI, supra note 2, at 7. As noted by Eisuke Sakakibara the ex-MOF bureaucrat once known as "Mr. Yeng "While career [MOF bureaucrats] rarely stay until retirement age, "non-career" bureaucrats often keep working until that time." EISUKe SAKAKIBARA, ZAimuSHo [The Ministry OF FINANCE] 78 (2012).

21. See generally ICHIRō ICHIIMURA, AmAKUdARI NO SHINJITSU [The Truth About AmAKUDARI], 60-80, 95-97 (2010) (discussing Amakudari). 
amakudari but to illustrate the effect it may have on the Japanese legal system. ${ }^{22}$

Rather than discussing amakudari further in general terms, however, it may be helpful to proceed with specific examples of how amakudari works. These examples will also hopefully illustrate the legal dimensions of the amakudari process.

\section{EXAMPLES OF AMAKUDARI IN PRACTICE}

\section{A. Private Sector Amakudari and Corporate Governance}

We begin with the Bank of Yokohama Co., Ltd. ("BOY"). $\mathrm{BOY}$ is one of the largest and most prestigious of the second tier "regional" commercial banks (chihōginkō ginkō). ${ }^{23}$ Founded in 1920, as of the end of the fiscal year ending March 31, 2013 it had 4,593 employees in 610 branches and offices, including a small overseas presence. ${ }^{24}$ As of the same date its consolidated assets and deposits totaled 13,468.7 billion yen and 11,450.2 billion Yen, respectively. BOY is a publicly-traded company; its shares are listed on the First Section of the Tokyo Stock Exchange (the "TSE"), which has the most stringent listing standards of any exchange in Japan. As of March 31, 2013, BOY's ten largest shareholders consisted of Japanese insurance companies, a US pension fund and several trust accounts. ${ }^{25}$

As of the year ended March 31, 2012, the most recent filing available at the time this article was written, BOY had a board consisting of eleven directors and five statutory auditors. As is

22. See Colignon \& UsUI, supra note 2, at 57-81 (discussing various theories of amakudari). Former MOF official Eisuke Sakakibara is one of those who describes amakudari as an unavoidable byproduct of Japan's system of lifetime employment and seniority-based advancement in both the public and private sectors. SAKAKIBARA, supra note 20 at 145.

23. Bank of Yokohama, BANKS AROUND THE WORLD, http://www.rel banks.com/asia/japan/bank-of-yokohama (last visited Mar. 4, 2014).

24. Corporate Data, BANK of YokOHAMA, (Sept. 30, 2013), http://www.boy.co.jp/e/company/data.html.

25. Stock Data, BANK OF YOKOHAMA, (Sept. 30, 2013), http://www.boy.co.jp/e/stock/data.htm. 
often the case with Japanese public companies, most of the directors were "insiders" who spent their whole careers at the bank. One director, however, had spent 25 years in the Ministry of International Trade and Industry (now the Ministry of Economy, Trade and Industry or "METI") before descending into the private sector. An additional board member was a former Bank of Japan official and another a former judge. ${ }^{26}$

Most significantly, however, both the president and the chairman of the BOY board were ex-top officials from the Ministry of Finance (MOF). President Tatsumaro Terazawa joined the MOF in 1971 and ended his career as the head of the National Tax Agency, a MOF subsidiary institution from which he retired in 2004. He then served several years at the Urban Renewal Agency, a special administrative corporation formed by the government, before being appointed as special ambassador to Columbia. In 2011, he joined the BOY, immediately assuming the presidency. It may seem odd that someone with apparently no experience in commercial banking - indeed, no business experience whatsoever - could immediately become the leader of a major commercial bank. Yet such transitions are not unusual in the world of amakudari.

Terazawa's transition into the world of bank management was likely eased by the presence of BOY's chairman, Tadashi Ogawa, who had served as BOY president from 2005 until Terazawa took over. ${ }^{27}$ Ogawa started his career at the MOF in 1962, retiring in 1996 after becoming vice minister - the most powerful bureaucrat at the nation's most powerful ministry. From that position he immediately assumed the chairmanship of Japan Tobacco, one of the largest tobacco companies in the world, which until 2012 was majority-owned by the Japanese government. ${ }^{28}$

26. Board of Directors, BANK of Yokohama, (June 19, 2013), http://www.boy.co.jp/e/company/board.html.

27. As of June 2013 Ogawa was no longer a board member.

28. The government continues to be the largest shareholder, though the register of shareholders lists the Minister of Finance, rather than the Japanese state as the shareholder of its stake. See sources cited, supra notes 25-26. 
The composition described above is not the result of mere happenstance. As indicated by Professor Masashi Nakano, the presidency of the BOY has, "as always," been held by an exMOF vice minister. ${ }^{29}$ Back in the days when the MOF was also the nation's financial regulator, MOF officials retiring into the boards of commercial banks was quite common; in 1993 it was reported that $26 \%$ of the presidents of Japan's private banks came from either the MOF or the Bank of Japan. ${ }^{30}$ With the financial regulatory function having been taken away from MOF, blatant instances of amakudari to board level positions such as BOY may now be the exception rather than the rule. Or perhaps the amakudari may simply have been driven down to a more discrete level - to "advisory" positions that do not have to be disclosed in regulatory filings, instead of board positions that do. ${ }^{31}$ Such a trend is suggested by a recent article in a weekly magazine, describing the troubles of Daiwa Securities which had three high level ex-MOF officials in advisory roles at an estimated cost of $¥ 200$ million per year - expenditures some Daiwa employees found demoralizing since the company was also engaged in cost-cutting and layoffs at the same time $!^{32}$

29. NAKANO, supra note 3, at 98.

30. Chalmers Johnson, The Foundations of Japan's Wealth and Power, in JAPAN: WHO GOVERns? 96, 108 (1996) (quoting an Oct. 1993 Nihonkeizai shinbun article).

31. Although Nakano notes the decline in amakudari by former MOF officials into regional banks since MOF lost the bank regulatory function, the list of public and private institutions having amakudari from the MOF contained in Ichimura's book lists over two dozen shin'yō kinko, a type of small regional depository institution referred to in English as either a "shinkin bank" or "credit union." NAKANO, supra note 3, at 98; see also ICHIIMURA, supra note 21, at 143-61. The preponderance of such institutions as MOF amakudari posts is interesting since, unlike regional banks and other types of financial institutions, no shinkin banks are public companies.

32. Omowanu keisan gai Daiwa Shōken ga atama wo kakaeru zaimushōo "amakudari" sannnin shū [Daiwa Miscalculation leaves it struggling with a crowd of three MOF "amakudari”], SHŪKAN GENDAI, May 25,2013 , at 79 (Japan). Since amakudari arrangements require the compensation and benefits to be comparable to that of a high-level bureaucrat, in addition to salary, Daiwa was reportedly required to provide these three gentlemen with private offices, a secretary and chauffeured black limousines - 
While much ink has been spilt regarding the subject of corporate governance in Japan, little consideration seems to have been given to what it means in the context of a company that has a former senior regulator on the payroll, whether as a board member or even an advisor. Yet it would seem impossible to have a meaningful discussion about the subject in normal corporate governance terms. Take an archetypical example used in corporate governance discourse - the takeover bid.

A public tender offer directed at a public company with the stated intent of replacing its management in order to enhance shareholder returns is a classic example of an instance in which the conflicting duties and interests of board members become an issue. Yet if the target company is BOY and succeeding in the bid would actually result in the most important central government ministry losing a lucrative post-retirement sinecure, it might actually be very bad for the company and its shareholders. This would probably be obvious to anyone in corporate Japan, yet, at the same time, seems difficult to incorporate into any law-based theory of corporate governance, possibly because just like outright corruption, the informal reservation of corporate leadership roles for ex-ministry officials may not be anticipated by such theories. Corporate governance may be about many things, but providing benefits to exbureaucrats outside of any legal framework is probably not supposed to be one of them. ${ }^{33}$

benefits they would have enjoyed at taxpayer expense in their former government roles. Despite such high compensation, a Daiwa insider quoted in the article declared that the three consultants did "absolutely nothing." The article speculated that they were hired as consultants on the expectation that one of them would be named Governor of the Bank of Japan, which unfortunately for Daiwa did not happen. $I d$.

33. For purposes of this article, however, it should simply be noted that the presence of former METI and other energy bureaucrats as advisors and board members in TEPCO and other companies has been noted in numerous press accounts. See, e.g., Keisanshō kara no amakudari denryoku 12sha he 68nin [Amakudari 68 former METI personnel into 12 electric power companies], Asahi Shinbun, (May 3, 2011), at 9 (Japan); Tōden komon wa 21nin, hōshūsogaku wa 2.2 okuen $[21$ advisors at TEPCO with total compensation of $¥ 210$ million], ASAHI SHINBUN, May 22, 2011, at 5 (Japan); 


\section{B. Home-grown Amakudari - Foundations and Other Special Entities}

Amakudari is a constant source of popular criticism and the nation's political leaders have developed a byzantine system of laws and regulations to eliminate or at least regulate the practice. For example, the National Public Service Act ("NPSA") imposes numerous prohibitions on government institutions pressuring companies into accepting retirees. ${ }^{34}$ The NPSA also makes it a crime for ex-public servants to use their influence with their former employer in various ways during the two year period immediately following their separation from public service. ${ }^{35}$

Yet the bureaucracies always seem to be able to find ways around such restrictions. ${ }^{36}$ Furthermore, insofar as 60 (or even 65 ) is a comparatively young retirement age, one might reasonably expect that finding a steady source of post-retirement jobs for retiring personnel would become just one of the managerial tasks that have become the burden of leaders of bureaucracies in Japan. As noted by one former bureaucrat, in this respect Ministries are no different from any other large

Natsuko Fukue, METI hit for "amakudari" habits that put advisors at TEPCO, THE JAPAN Times Apr. 19, 2011, http://www.japantimes.co.jp/news/2011/04/ 19/business/meti-hit-for-amakudari-habits-that-put-retirees-intepco/\#.UkqtZRC9Xg4.

34. See Kokkakōmuinhō [National Public Service Act], Law No. 120 of 1947, arts. 106-07 (Japan), translated in Japanese Law Translation, MinISTRY OF JUST. (Apr. 1, 2009), http://www.japaneselawtranslation.go.jp/ law/detail/?id $=2141 \& \mathrm{vm}=04 \& \mathrm{re}=02$.

35. See id. art. 110 (xiv-xviii).

36. KogA, supra note 16, at 123-28. Koga describes how a government originally intended to expand the horizons of junior public servants by temporarily seconding them to companies, came to be used as a means for "seconding" elder bureaucrats to companies or other institutions just a few years before they reached retirement age. That way they could simply end their public service already installed at their post retirement job. The laws and regulations were carefully drafted (by bureaucrats) to ensure that this sort of result did not constitute legally prohibited amakudari. Id. 
Japanese institution, most companies having a similar low mandatory retirement age. ${ }^{37}$

The difference between Japanese bureaucrats and corporate leaders, however, is that bureaucrats are in a position to create new post-retirement jobs out of whole cloth through their effective control of the legislative process. Although the Japanese constitution vests in the Diet (the nation's parliament) the "sole law-making authority," in reality the vast majority of legislation passed by the Diet is actually initiated by the Cabinet and thus drafted primarily by the relevant government agencies. ${ }^{38}$ The Cabinet has the assistance of the Cabinet Legislation Bureau, arguably one of the most important of the national bureaucratic institutions in the central government, and one in which all of the top ministries are represented through employees on secondment. With much of the nation's legislative business being conducted by bureaucrats, Diet members are left performing a role described by one ex-bureaucrat as "something similar to lobbyists in the US System." 39

It is easy to identify which ministry is responsible for which laws, since each has a link on its website identifying the laws and regulations under its jurisdiction (shokan hōrei). Some go so

37. SAKAKIBARA, supra note 20, at 144.

38. See Recently Submitted Proposed Legislation, CABINET LEGisLATION BUREAU, http://www.clb.go.jp/contents/all.html (last visited Mar. 4, 2014) (Japan) (according to Japan's Cabinet Legislation Bureau ("CLB"), during the $183^{\text {rd }}$ (Ordinary) Diet Session which ran from January 28 to June 26, 2013, the Cabinet submitted to the Diet 75 bills, 63 of which became law. By contrast, of 81 bills submitted by Diet members, only 10 were passed into law). At the risk of oversimplifying, legislation submitted by the Cabinet can generally be assume more likely to be of bureaucratic origin and having been vetted by the CLB - one of the most powerful executive branch institutions will likely have taken into account the interests of the various bureaucratic interests represented in the CLB and potentially affected by the legislation; see generally Richard Samuels, Politics, Security Policy, and Japan's Cabinet Legislation Bureau: Who Elected These Guys, Anyway? JAPAN PoLICY RESEARCh Institute, Working PAPER No. 99 (March 2004), available at http://www.jpri.org/publications/workingpapers/wp99.html, for further discussion of the CLB in English.

39. SAKAKIBARA, supra note 20 , at 78. 
far as to list laws that have been submitted to the Diet but are still pending, coming awfully close to creating the appearance that it is actually the ministries themselves that propose the laws that they would administer if passed (which may actually be the case).

The legislative system thus offers bureaucrats ample opportunities to draft laws to further ministry interests, while taking into account the concerns of other ministries as well. These interests may include a regular supply of post-retirement jobs for ministry personnel.

One way of creating such a supply is for the ministry to simply create a special administrative corporation (dokuritsu gyōsei hōjin) or ostensibly private but actually quasi-public (i.e. directly or indirectly publicly funded) institution as part of a policy initiative. The institution is typically a foundation or "public interest" corporation and its charter provides for a higher retirement age than the public service; bureaucrats can retire into it as directors or line employees, depending upon their place in the ministry hierarchy. ${ }^{40}$ The purpose of the institution is shaped by the law which creates it and the policies it is supposed to be implementing. It may receive its initial funding from the government and receive various government subsidies, but may also enjoy a stable source of revenue through no-bid contracts with the ministry that created it, membership fees from stakeholders subject to ministry regulation, or through the exercise of a formal or de facto monopoly over the exercise of some function in a regulatory scheme that requires companies or persons to pay the foundation for the performance of this function. Which foundations and other entities "belong" to a particular ministry are also easy to identify, since just as ministry

40. WoODALL, supra note 1, at 74 ("It is not much of an exaggeration to the positions assumed [at such institutions] by these former high-level bureaucrats as sinecures. The posts - president, vice-president, member of the board of directors and auditor - usually entail few duties other than ceremonial functions and bring an annual salary well in excess of $\$ 100,000$, a healthy sinecure indeed. And all the more so with generous retirement allowances."). 
websites also contain links to their shokanhōjin, the corporate entities over which they have jurisdiction.

In a recent book, a former top METI official describes how the foundation-creating process works. ${ }^{41}$

"For example, say there are a number of incidents involving food safety. Naturally, the people get angry and complain "How can this be allowed to happen? How can we feel safe about eating anything?" Then, at just the right time a bureaucrat from the Ministry of Health Welfare and Labor or perhaps the Food Safety Commission shows up and says "Okay we will do something to help."

The bureaucrats look like they are the peoples' friends, right? And what they do is implement a law that creates new regulations, or amends existing law to make the rules more stringent.

Both the media and the people approve and while they are saying "yes, yes, well done" the curtain goes down to applause. This is the "public picture" but it is at this point that the bureaucrats' most important task begins.

They will say "in the law let's make it clear that 'for implementation the government will take steps to inform and enlighten the public'. And an organization will be needed to implement the detailed regulations, so let's make a new entity. An entity for each prefecture would also be good."

In this way, with nobody noticing, various things get attached to the new program. Using this law as leverage, a budget request is made using the assertion that "if we can't do the various things mandated by law terrible things will happen." In addition, industry groups are engaged with the following line of discussion: "The regulations are going to get more stringent, so it is going to be tough on you. How do you plan to implement them and inform people? You can't do it with your existing industry association can you? So let us make you

41. KogA, supra note 16 , at 123-28. 
a new organization. Your existing one is not good enough to keep the people safe."

Actually the existing organization provably is adequate, but a new one is made anyways. Of course, companies become members of that organization and give it money in the form of membership fees or cooperation fees. At the same time, the organization says "if we leave it to just a few companies it will not be impartial, so the country will send some OBs ["old boys" = retired bureaucrats]." The Director is a former career bureaucrat, and the general manager is a former non-career bureaucrat.

With this a new amakudari program is complete!",42

This is a cynical characterization written for a general audience in a mass-market non-fiction book. It is nonetheless probably not an inaccurate description of how some forms of amakudari work - in fact once one becomes sensitive to this dynamic, virtually every foundation or association purporting to serve a public service becomes suspect as a possible amakudari vehicle.

\section{Jigyō Shiwake - A Window Into the World of Amakudari Foundations}

One of the remarkable accomplishments of the short-lived Democratic Party of Japan administration was its 2010 jigyō shiwake (literally "sorting out operations") campaign. Jigyō shiwake was an effort to shine a spotlight on the incestuous collusion between government institutions and foundations of various types that both served as mediums for amakudari but also enjoyed a privileged status within various regulatory regimes. Jigyō shiwake was dismissed as political theater by some; despite publicizing seemingly ridiculous examples of government waste, collusion and amakudari, recommendations

42. Id. at 83-84. 
that they be eliminated made by the panels of politicians, academics and others who conducted the reviews were nonbinding, and many of the foundations identified as problematic remain in existence. ${ }^{43}$

Nonetheless, the reports resulting from the process make some of the most illuminating, not to mention entertaining reading on the grubby realities of the process of governmentmanufactured amakudari. ${ }^{44}$ Space allows only a few examples: was it necessary in this day and age for the Salt Industry Center of Japan - a foundation - to be acting as an emergency supply of a basic and widely available commodity like salt? More to the point, was it necessary for such a foundation to have accumulated net assets worth over $¥ 60$ billion, including $¥ 43$ billion in marketable securities? ${ }^{45}$ Similarly, allowing the Airport Environment Improvement Foundation to lease public land at

43. See, e.g., Jigyo shiwake, gekijogata yame, jimichi ni tenken wo [Jigyo Shiwake: instead of theatrics, a sober evaluation], GIFU SHINBUN (Nov. 26, 2012), http://www.gifu-np.co.jp/column/syasetsu/sya20121126.shtml (Japan) (noting criticism of the process as "just a show" and having no basis in law).

44. See Business Sorting, Gov't Revitalization Unit (Apr.-May 2010), http://www.cao.go.jp/sasshin/shiwake.html (Japan), for more information on the official records of the jigyo shiwake [business sorting] process.

45. Gov't Revitalization Unit, Jigyoshiwake Salt Center Foundation SECtion meEting notes [hereinafter SAlt Center Notes] 2, available at http:/www.cao.go.jp/sasshin/shiwake/detail/gijiroku/a-26.pdf (Japan); see generally Gov'T Revitalization Unit, SAlt CENTER Evaluation REPORT [hereinafter SAlt CENTER Evaluation REPORT], available at http:/www.cao.go.jp/sasshin/data/shiwake/result/A-26.pdf (describing Salt Center meeting). According to the Salt Center Notes, this foundation had a single full-time director who was a former bureaucrat. SALT Center Notes, at 5. Note that the Salt Center Foundation traces its roots back to when salt and tobacco were both government-controlled monopolies. A significant portion of the foundation's assets were transferred together with the salt business from Japan Tobacco in 1996, and the Evaluation Report recommended that such assets be returned to the national treasury. SALT Center Evaluation RePORT, at 2. This illustrates one other aspect of the amakudari system; that it may result in significant amounts of ostensibly public funds becoming lodged in quasi-private entities that nonetheless remain under the control of insiders from a particular Ministry. 
low rents to use as airport parking lots and then use the profits garnered for investments in whatever environmental improvements its board felt appropriate with no public supervision whatsoever was similarly "difficult to understand."46 Of the foundation's twelve directors, five were ministry "old boys" (OBs), including three of the five full-time directors. ${ }^{47}$ Just over half of its 234 full and part-time employees were also exbureaucrats, illustrating that amakudari is not just a matter of jobs for former- ministry high-fliers.

More examples: some evaluators questioned whether the Snow Research Center could perform its stated mandate of "considering how to manage winter road surfaces and how to test and evaluate snow-clearing equipment" from its headquarters in

46. See generally Gov't REVITALIZATION Unit, Jigyo SHIWAKE Airport ENV'T IMPROVEMENT Foundation SECTION NOTES AND EVALUATION REPORT (Japan), available at http://www.cao.go.jp/sasshin/shiwake/detail/ 2010-05-20.html (illustrating what may be another feature of this sort of Amakudari vehicle). The Report indicates that a particular group of current or ex-bureaucrats could use public resources to engage in activities they consider to in the public interest, but without public oversight or accountability. Another example of this dynamic was brought to light by a 2010 newspaper report about ex-supreme court justice Yasukazu Kagawa who at the age of 88, was able to receive a $¥ 15$ million loan with no repayment terms and a sudden doubling of the salary he was receiving from the now-defunct Minji Johō Center, a nowdefunct foundation affiliated with the Ministry of Justice. See Ex-justice taps body for easy loan, raise, THE JAPAN TIMES (Apr. 14, 2010), http://www.japan times.co.jp/news/2010/04/14/national/ex-justice-taps-body-for-easy-loanraise/\#.Ui_Q6z-9Xg4. Kagawa reportedly had no intention of repaying the loan since he was using it to fund an essay contest, and no board action was taken on either the loan or the salary increase until several months after they were made. Although the Ministry of Justice and judiciary are both key actors in the development of corporate governance, actual corporate governance is apparently something that only happens to commercial businesses.

47. It seems to be a common feature of foundations and other entities that serve as amakudari vehicles that they have various large boards, the majority of whom are academics or non-government OBs. Closer investigation reveals that only a few board members are "full-time" (jōkin) directors of the type that would receive a regular salary from the organization. While ministry OBs are usually a small minority when compared to the total board, they account for a significant number of the full time directors (sometimes being the only full-time director). 
the fashionable (and generally snow-free) Nihonbashi district at the center of Tokyo. ${ }^{48}$ The location may have been convenient for the five out of fourteen directors (including the sole full-time director) and four out of fourteen employees who were Ministry $\mathrm{OB}^{49}$

Although the jigyō shiwake process took place the year before the March 11, 2011 nuclear disaster at Fukushima, in hindsight it may rankle to learn that the Japan Industrial Location Center $^{50}$ (OB: five of twenty directors (including two of four full-time directors), two of 44 employees) and the Japan Atomic Energy Relations Organization (OB: two of thirty-six (!) directors, zero of thirty four employees) were placing advertisements in cooking magazines to foster support for nuclear power amongst Japanese homemakers. ${ }^{51}$

48. See Gov't Revitalization Unit, Snow Research Center EVALUATION REPORT 3, available at http://www.cao.go.jp/sasshin/shiwake/ detail/2010-05-21.html (last visited Feb. 10, 2014) The Snow Research Center has a website. SNOw RES. CENTER, http://www.yukicenter.or.jp/ (last visited Feb. 11, 2014).

49. As many directors as employees!

50. English Page, JAPANESE Indus. LOCATION CENTER, http://www.jilc.or.jp/en/index.html (last visited Feb. 11, 2014).

51. JAPAN ATOMIC ENERGY Rel. ORG., http://www.jaero.or.jp/ (last visited Feb. 10, 2014); see generally Gov'T REVITALIZATION UNIT, EVALUATION REPORT ON Jigyo SHIWAKE [hereinafter EVALUATION REPORT ON JIGYO SHIWAKE], available at http://www.cao.go.jp/sasshin/shiwake/detail/ 2010-05-20.html (last visited Feb. 10, 2014) (on file with author) (describing the Japanese nuclear energy sector's marketing efforts). This sort of activity is just the tip of the iceberg when it comes to spending on pro-nuclear marketing. 13.8 billion yen was reportedly spent on government funded pro-nuclear advertising and pointless "research," much of it filtered through amakudari institutions which had no-bid contracts with the government but ended up outsourcing the substantive task at market rates to outside vendors, meaning the government ended up massively overpaying for commercial services with the bulk going to meeting the institution's payroll. "Genpatsu wa anzen" ni 138 oku, keisanshō amakudari dantai he no genpatsu hojokin risutō [13.8 billion for "Nuclear Power is Safe" - a list of subsidies to METI amakudari organizations], JAERO, (Aug. 8, 2011), http://www.jaero.or.jp/ (Japan). Depressingly, in the two years after the Fukushima meltdown, the government spent almost $¥ 2.5$ billion marketing nuclear power, with approximately $70 \%$ of this amount going to institutions with government OB and TEPCO alumni on 
People who have studied Japanese at a language school in Japan may be surprised to know that the foundation that accredits such institutions, the Association for Promotion of Japanese Language Education (APJLE), ${ }^{52}$ has been under the jurisdiction of the Ministry of Justice (MOJ) rather than educational authorities. This relationship is illustrated by the fact that three of the APJLE's directors were ex-immigration bureau officials (the immigration system being under the jurisdiction of the MOJ). ${ }^{53}$ This may explain why the foundation's accrediting requirements for Japanese language schools seem devoted as much to ensuring compliance with student visa requirements as with teaching Japanese properly. ${ }^{54}$ It might also explain the odd

their boards. Kuni no genpatsu kōhō jiko go 25 okuen, amakudari denryokukei ga $66 \%$ juch $\bar{u}$ [After accident, government spends $¥ 2.5$ billion on nuclear marketing, 66\% goes to amakudari and electric company-affiliates, AsAHI SHINBuN (June 17, 2013), at 1 (Japan), http://www.jaero.or.jp/; http://www.jilc.or.jp/; see generally Jigyō Shiwake, Gov'T REviTALIZATION UNIT, http://www.cao.go.jp/sasshin/shiwake/detail/2010-05-20.html (last visited Mar. 31, 2014), for jigyō shiwake notes and reports (on file with author).

52. Ass'N FOR Promotion JaPANese LANGuage Educ., http://www.nisshinkyo.org/english/index.html (last visited Feb. 10, 2014).

53. The Association has apparently recently stopped giving full details regarding its directors on its website, listing only its "principal directors" [omōna yakuin]. ASS'N FOR PROMOTION JAPANESE LANGUAGE EDUC., http://www.nisshinkyo.org/review/index.html (last visited Feb. 10, 2014). The author's assertion that there were ex-immigration officials is based on memory from looking at directors' lists when there was full disclosure about the directors and their backgrounds on the website. The Jigyō Shiwake Report $\left(2^{\text {nd }}\right.$ Round) notes that the foundation only has four full time employees, three of whom are government OB. GOV'T REVITALIZATION UNIT, ASSOCIATION FOR THE Promotion of JAPANESE LANGUAGe Education EVAluation RePORT ( $2^{\mathrm{ND}}$ ROUND) 106-07, [hereinafter APJLE REPORT], available at http://www.cao.go.jp/sasshin/shiwake.html (last visited Feb. 10, 2014) (Japan) (on file with author).

54. See The Criteria for the Operation of Japanese Educational Institutions, ASs'N FOR PROMOTION JAPANESE LANGUAGE EDUC., available at http://www.nisshinkyo.org/review/index.html (last visited Feb. 10, 2014). The assertion that they are focused on immigration compliance rather than educational content is a subjective one made by the author. In 2012 for reasons unrelated to this research the author had the opportunity to talk with the operators of several Japanese language schools, all of whom confirmed that even though accreditation was not a formal requirement being accredited by the 
yet reasonable suggestion made by one jigyō shiwake evaluator that "some sort of system should be developed for evaluating the quality of Japanese language education" (as opposed to evaluating schools, apparently). ${ }^{55}$

In connection with the legal system, it is noteworthy that one of the more egregious examples of an amakudari mechanism brought to light through the Jigyō shiwake process involved the MOJ and its captive public-interest foundation, the Japan Correctional Association (JCA) ${ }^{56}$ With government OB as 11 of its 24 directors (including both full time directors) and 19 of its 53 employees, the JCA supplies materials to prison manufacturing operations and provides the sundries purchased by the nation's prison population, a nicely captive market. As noted by the Jigyo shiwake evaluation report, its chairmanship had become the designated retirement spot for the Supreme Prosecutor (kenji sōchō), the nation's top prosecutor and also top career official at the MOJ (which regulates the entire correctional system). ${ }^{57}$ Not only that, but a portion of its expenses - including the $¥ 6$ million a year salary paid to the chairman (a part-time

Association greatly facilitated the issuance of student visas to persons seeking to come to Japan to study Japanese. If this were the case, it would suggest another feature of amakudari systems as they pertain to the legal system is that they can result in the creation of regulatory requirements that are not actually founded in law. As concluded by the Report, "The legal justification is that the results of an evaluation conducted by a private sector organization with only four full-time employees, three of whom are government $\mathrm{OB}$, is 'used for reference' (sankō ni suru), it is unclear whether it is necessary to go through this Association and the appropriateness of the evaluation fees and renewal fees being charged is also problematic. We conclude that the system should be made legally clear, and that these operations [evaluation of Japanese language schools by the Association] should be terminated." APJLE REPORT, supra note 53.

55. Id.

56. JAPANESE CORRECTIONAL Ass'N, http://www.kyousei-k.gr.jp/ (last visited Feb. 10, 2014).

57. Gov't ReVitalization Unit, JAPANESE CORReCtional Ass'N EVALUATION REPORT 2-3, [hereinafter JCA REPORT] http://www.cao.go.jp/ sasshin/shiwake/detail/2010-05-25.html (last visited Feb. 10, 2014) (on file with author). 
role) - were met through supposedly voluntary contributions from prison guards. ${ }^{58}$

\section{HOW AMAKUdARI FoUndATIONS MAY SHAPE THE LAW}

While the records of the jigyō shiwake process provide numerous opportunities for voyeuristic insights into amakudari and other forms of institutional nepotism in Japan, let us step back to focus on some more specific examples of how amakudari can affect the structure and functioning of the legal system itself. As hinted at in the example of the APLJE in the preceding section, a common approach is to include in a law some licensing, accrediting or other similar requirement. The official confirmation that this requirement has been satisfied is then delegated to a body or institution designated by the regulator. The accrediting or other requirement may seem neutral or reasonable on its face and may even be substantively legitimate; the point is that the applicable regulator essentially grants to an ostensibly private body a virtual monopoly on performing that function, or if not a monopoly, a significant competitive advantage in doing so.

Examples that came up during the jigyō shiwake process included the requirement that licensed pilots have periodic medical exams. This is a perfectly legitimate regulatory requirement, of course, but the evaluators questioned why they had to be performed by "designated" professionals and organizations, including the government-affiliated Japan Aeromedical Research Center ((JARC), which five of 13

58. As queried by one of the members of the working group committee meeting held on May 25, 2013, "So you are taking membership fees from prison guards who are on the job and who probably aren't highly paid. Since 98\% of them participated, they are essentially being forced to pay these fees, some of which go to paying $¥ 6$ million a year to an ex-supreme prosecutor who of course is qualified as a lawyer and can easily earn a living practicing law; do you think these people can accept paying such a person six million yen?" JCA REPORT, supra note 57. Possibly because of the bad publicity resulting from this process, at the time of writing the chairman of the JCA was a respected professor of criminal law rather than an ex-prosecutor. 
directors and one of 27 employees being government OB) ${ }^{59} \mathrm{~A}$ similar legal requirement that janitors receive yearly training of the sort offered by the National Cleaning Service Guidance Center (three of 21 directors and four of ten employees were government $\mathrm{OB}$ ) was deemed incomprehensible. ${ }^{60}$

These examples may seem minor or even amusing, but others (some of which notably were not covered in the jigyo shiwake process) can involve serious money. Take the supposedly quaint Japanese pastime known as pachinko. Nothing more than a form of legalized gambling in a country where gambling is nominally illegal, Pachinko generates approximately $¥ 20$ trillion in sales annually. ${ }^{61}$

Although pachinko has traditionally been a mechanical game involving balls and a pin table, many pachinko parlors now feature casino-like slot machines. Under the Act for the Control and Improvement of Amusement Businesses, all pachinko machines must meet standards established by the National Public Safety Commission, including criteria intended to prevent the

59. Gov'T REVITALIZATION Unit, http://www.cao.go.jp/sasshin/ shiwake/detail/2010-05-20.html (last visited Feb. 10, 2014) (on file with author); JAPANESE AERONAUTICAL RES. CENTER, http://www.aeromedical.or.jp/ (last visited Feb. 10, 2014). The requirement for pilots to have medical checks from qualifying doctors is from Article 31 of the Civil Aeronautics Act. Kōkūhō [Civil Aeronautics Act], Law No. 231 of 1952, art. 31 (Japan), English translation available at http://www.japaneselawtranslation.go.jp/law/detail/? $\mathrm{re}=02 \& \mathrm{dn}=1 \& \mathrm{x}=32 \& \mathrm{y}=10 \& \mathrm{co}=1 \& \mathrm{ha}=02 \& \mathrm{ia}=03 \& \mathrm{yo}=\& \mathrm{gn}=\& \mathrm{sy}=\& \mathrm{ht}=\& \mathrm{no}=$ $\& \mathrm{bu}=\& \mathrm{ta}=\& \mathrm{ky}=$ the + civil + aeronautics + act $\&$ page $=5$.

60. APJLE REPORT, supra note 53, at 117-18; ZENKOKU SEIKATSU EISEI Eigyō Shidō Sentā [National Cleaning Service Guidance Center], http://www.seiei.or.jp/top/index.html (last visited Feb. 10, 2012) (Japan). The legal basis for the training requirement can be found at Article 8-3 of the Cleaning Business Law. Kurīningu jigyōhō [Cleaning Business Act], Law No. 207 of 1950 (Japan).

61. According to the most recent information available on the website of Nichiyukyo, a pachinko industry trade association, total sales for the industry in 2010 and 2009 were approximately $¥ 21$ trillion respectively. Massive though these numbers are, they represent a significant decline from peak sales of $¥ 29.6$ million in 2003. Income, Participants, and Number of Activities, NichIYUKYo, http://www.nichiyukyo.or.jp/condition/ (last visited Feb. 10, 2014) (Japan). 
use of machines that excessively stimulates players' desire to gamble (because it's not gambling, you see). ${ }^{62}$ The same Act also delegates many of the details of this standard-setting to subsidiary regulations and local rules which require all types of Pachinko machines to pass a test conducted by a designated testing body. ${ }^{63}$ One such testing body is a foundation known as the Security Communications Association, which provides a variety of services but derived $¥ 2$ billion in revenue in 2012 from pachinko machine testing. ${ }^{64}$ Four of the association's 12 directors were former bureaucrats, including three of its four full-time directors who were formerly officials from national and prefectural police organizations. ${ }^{65}$

62. Fūzoku eigyōtō no kisei oyobi gyōmu no tekiseikatō ni kansuru hōritsu [Act for the Control and Improvement of Amusement Businesses], Law No. 122 of 1948 (Japan).

63. Yūgiki no nintei oyōbi keishiki no kenteitō ni kansuru kisōku [Rules for the Accrediting and Certification Testing of Entertainment Devices], National Public Safety Commission Rule 4 of 1985, art. 12 (Japan). The Japanese police are organized primarily on a prefectural rather than national basis, meaning that there are also local rules on Pachinko certification. For example, the Ehime Prefectural police regulations on certification require the relevant section of the prefectural police to certify pachinko machines, except that those using microprocessors (which would be all of them in this day and age) must be certified by a designated testing agency. Yūgiki no nintei oyōbi kentei ni kansuru jimu no toriatsukai yōryō [Guidelines for Processing the Certification and Evaluation of Entertainment Devices], Regulation No. 1 of Jan. 22, 1986 (Japan), available at vhttp://www.police.pref.ehime.jp/kitei/data $/$ reiki/hen $4 / 4502050 . h t m$. While beyond the scope of this article, the possibility of this sort of certification requirement functioning could act as a non-tariff trade barrier is hopefully obvious.

64. Revenue and director information as available at the time of writing on the association's website. SECURITY COMM. Ass'N, http://www.hotsukyo.or.jp/index.html (last visited Feb. 10, 2014). In his 2005 expose of the pachinko industry, journalist Atsushi Mizoguchi describes the Security Communication Association as being the only certifying body in Japan. He also interviews the Association's ex-chairman, an 84 year-old former head of the National Police Agency who explained that he only went to its offices once a month or so. MizoGuCHI ATSUSHI, PACHINKō "30 CHŌEN NO YAMI” [PACHINKO: ¥30 TRILLION OF DARKNESS] (2005) 183-87.

65. What appears common in these types of foundations is that they often have a large number of directors of various types, most of whom are parttime (hijōkin) and are often academics or representatives of various stakeholder 
There is of course a chicken-and-egg aspect to the role such foundations play in the legal system. In some cases they may fulfill a necessary function that just happens to have been coopted to the extent necessary to benefit a few ex-officials; in others, the legal requirement may have been created with such benefits being one of the intended goals. Which came first may not really matter because either way the result would seem to be a legal structure that is both difficult to change (insofar as it would require the ministry responsible for amending the law to do so in a way which caused it to lose a program beneficial to its personnel) and potentially impolitic for anyone subject to the ministry's jurisdiction to openly criticize.

In some cases, Amakudari may also provide a means of interagency compromise. This is illustrated by Japan's apparent solution to the question that has long plagued intellectual property specialists - should computer programs be protected by patent or copyright? ${ }^{66}$ In Japan, patents and trademarks fall under the jurisdiction of the Patent Agency, a METI subsidiary agency, while copyright is the mandate of the Agency for Cultural Affairs (ACA), under the Ministry of Education, Culture, Sports, Science and Technology (commonly abbreviated "MEXT"). ${ }^{67}$ This potentially serious jurisdictional dispute appears to have been resolved through a combination of a provision in the Copyright Act making it clear that computer programs are "works" in which authors could enjoy rights protected under the act, and a special statute requiring that such copyrights be registered not with the ACA, as is the case with copyrights in other types of works, but with an institution designated by the

groups. The former bureaucrats may represent a minority but tend to dominate the full-time (jōkin) directorships, which would mean they would be getting a full-time salary.

66. See, e.g., John Swinson, Patent or Copyright or Both: An Algorithmic Approach to Computer Software Protection, 5 HARV. J. L. \& TECH. 146 (1991).

67. Japan Pat. Off., JPO, http://www.jpo.go.jp/index.htm (last visited Feb. 8, 2014); AGENCY FOR CUlTURAL AFF., http://www.bunka.go.jp/ chosakuken/ (last visited Feb. 8, 2014). 
ACA. ${ }^{68}$ That institution is the seemingly innocuous Software Information Center (SOFTIC), a foundation that provides a variety of software-related services (including dispute resolution). ${ }^{69}$ Of the 22 foundation's 22 various types of board members at the time of writing (compared to only 16 employees of various types) three were former patent agency officials including one filling one of the two full time directorships - and another from the Small and Medium Enterprise Agency, another METI affiliate. ${ }^{70}$ Nobody from the ACA was represented on the board, though it retained legal jurisdiction over software copyrights and the authority to designate the institution empowered to register software copyrights. ${ }^{71}$

A detailed discussion of the substantive merits of outsourcing the government role of the registration of software copyrights is beyond the scope of this paper. While SOFTIC appears to ensure a generous salary for at least one former patent agency official, the revenues it generates directly from performing this role appears small - just over $¥ 5$ million in the year ending March 31 , 2013 , compared to total operating revenues of $¥ 608$ million for the same period. ${ }^{72}$ Nonetheless, the fact remains that an

68. Chosakukenhō [Copyright Act], Law No. 48 of 1970, art. 10(1)(ix) (Japan), English translation available at http://www.japaneselawtranslation.

go.jp/?re=01(translating law into English); Purōguramū no chosakubutū ni kakawarū torokū no tokurei ni kansurū horitsū [Law on Exceptional provisions for the registration of program works], Law No. 65 of 1986, art. 5 (Japan), available at http://www.wipo.int/wipolex/en/text.jsp?file_id=214983.

69. SOFTWARE INFO. CENTER, http://www.softic.or.jp/en/index.html (last visited Feb. 21, 2014).

70. See generally Roster of Councilors, Auditors and Directors SOFTWARE INFO. CENTER, available at http://www.softic.or.jp/lib/info_pub/yakuin-meibo.pdf (describing Japanese copyright protections).

71. Public Information, SOFTwARE INFO. CENTER, http://www.softic.or.jp/lib/info_pub/index.html (last visited Feb. 21, 2014).

72. Id. According to the disclosure also available on the website, fulltime director from the patent agency was entitled to a monthly salary of $¥ 950,000$ per month plus discretionary bonus plus a lump-sum upon retirement calculated at the rate of approximately $¥ 118,750$ for each month of service. Note that since such directorships are assumed by people who may only serve for a few years before they retire from them, cycling through several 
ostensibly private foundation from which ex-bureaucrats derive benefits is now in control of a basic government function, the registering of copyrights. More importantly, perhaps, the registration function is being performed not by a (theoretically) neutral government actor, but by a foundation that has additional revenues from membership fees paid by large electronic companies and other IT companies, interests that doubtless have a particular view of the way software copyrights should be administered. $^{73}$

\section{AMAKUdARI AND THE PRIVATE-SECTOR LEGAL PROFESSIONS}

\section{A. Law schools and the Artificial "Hōsō Population Problem"}

The creation and operation of foundations are not the only way in which the legal system provides post-retirement opportunities for bureaucrats. Let us turn now to the legal services industry in Japan. This is a particularly timely subject since at the time of writing Japan was in the throes of its first decade of disastrous (so far) reforms to the way it trained some of its legal professionals, particularly lawyers, a problematic term as we shall see.

One of the pillars of legal system reform in Japan has been an increase in the number of people passing the governmentadministered National Bar Exam (NBE) and requiring most of those who sit for the exam to have obtained a J.D. degree from an graduate law school. ${ }^{74}$ As part of this reform an entirely new system of law schools began operations in 2004. At one time

directorships would potentially enable an ex-bureaucrat to receive several such lump-sum payments.

73. Id. A membership list is also available on the foundation's website.

74. See Justice Sys. Reform Council, Recommendations of the Justice System Reform Council - For a Justice System to Support JAPAN IN THE 21st CENTURY, ch. III, pt. 2 (2001), available at http://www.kantei.go.jp/foreign/judiciary/2001/0612report.html. 
there were as many 74 law schools, all opened based on a cabinet-level decision to have 3,000 people passing the bar exam each year by $2010 .^{75}$

Almost as soon as the first crop of law students graduated in 2006, however, a hue and cry began to arise from bar associations about the sudden increase in the number of lawyers (bar exam passers may also become judges or prosecutors, but the principle increase has been seen only in the number of lawyers). ${ }^{76}$ Such opposition has resulted in a reduction in the number of people allowed to pass the NBE every year, a disastrous result for the law schools, of which there were too many even at the 3,000 level. ${ }^{77}$ Politics and unsubstantiated assertions about "poor quality" law school education resulted in the 3,000 target never being reached. The number of people who

75. Shihōseidō kaikakū suishin keikakū [Plan for advancing justice system reform], Cabinet Res. of Mar. 19, 2002 (Japan), available at http://www.kantei.go.jp/jp/singi/sihou/keikaku/020319keikaku.html.

76. For example, the Aichi Prefecture Bar Association had issued a formal opinion calling for a reassessment of the 3,000 per year number by February 13, 2007, This was at a time before a single one of the 1,009 law school graduates who passed the NBE in 2006 had qualified to practice law (all of those who graduated and passed the NBE in 2006 would have still been in the early stage of their required training course at the Supreme Court's Legal Research and Training Institute). Opinion on lawyer population, AICHI BAR Ass'N (Feb. 13, 2007), http://www.aiben.jp/page/frombars/topics2/272zinko u.html.

77. A detailed discussion of the law school system is beyond the scope of this paper. In any case, there is a wide range of literature on the subject available in English. See, e.g., Mayumi Saegusa, Why the Japanese Law School System Was Established: Co-optation as a Defensive Tactic in the Face of Global Pressures, 34 LAW \& Soc. InQuiry 365 (2009); Colin P.A. Jones, Japan's New Law Schools: The Story So Far, 27 J. JAPANESE L. 248 (2009); Peter A. Joy et al., Building Clinical Legal Education Programs in a Country Without a Tradition of Graduate Professional Legal Education: Japan Educational Reform as a Case Study, 13 CliniCal L. REV. 417 (2006); George Schumann, Beyond Litigation: Legal Education Reform in Japan and What Japan's New Lawyers Will Do, 13 U. Miami InT'L \& Comp. L. Rev. 475 (2006); Takahiro Saito, The Tragedy of Japanese Legal Education: Japanese "American" Law Schools, 24 WIS. INT'L L. J. 197 (2006); Koichirō Fujikura, Reform of Legal Education in Japan: The Creation of Law Schools Without a Professional Sense of Mission, 75 TUL. L. R. 941 (2001). 
passed the NBE in 2013 bar was only 2049, and bar associations have been calling for the number of passers to be reduced to as low as 1,000 or even for the law school system to be abolished entirely. ${ }^{78}$ According to press accounts and the vested interests involved, Japan was in the throes of dealing with a hōsō population problem - an oversupply of people who have passed the NBE.

This state of affairs has led to a prolonged debate about the "correct" number of hōsō, the Japanese term used to refer to the triumvirate of bengoshi lawyers, judges and prosecutors who have passed the NBE. The debate is surreal for a number of reasons. First the notion that there is an identifiable "correct" number of annual bar passers that can be designated by the government is questionable to say the least, yet forms the very foundation of the debate. Second, despite such open discussions about what in an anti-trust context might be considered a form of "production restrictions," the statutory fiction underlying the NBE - that it is intended to ensure that passers have the minimum levels of knowledge and ability to practice law ${ }^{79}$ often results in the low NBE pass rate being attributed to the "quality" of law school education. ${ }^{80}$ This in turn is surreal

78. See, e.g., Legal Profession Population Problem Project Team, HYOGŌ-KEN BAR Ass'N, http://www.hyogoben.or.jp/about/index-03-18.html (last visited Feb. 16, 2014) (stating the resolution passed by the Hyogō Bar Association calling for number of passers to be reduced to 1,000 per year). A 2012 Advisory Opinion issued by the Japan Federation of Bar Associations noted that its membership included lawyers who were calling for the complete abolition of the law school system. JAPAN FED'N OF BAR ASS'NS, HOKADAIGAKUIN SEIDŌ NO KAIZEN NI KANSURŪ GUTAITEKI TEIGEN [SPECIFIC PROPOSALS IN CONNECTION WITH IMPROVING THE LAW SCHOOL SYSTEM] 6 (2012), available at http://www.nichibenren.or.jp/activity/document/opinion/year/ 2012.html.

79. Shihōshikenhō [National Bar Exam Act], Law No. 140 of 1949, art. 1 (Japan).

80. Despite supposedly being intended to test whether candidates have the minimum level of knowledge required to be an attorney, judge or prosecutor, the bar exam pass rate is essentially derived from the number of people who the government allows to pass any given year over the number of people who sit for it. Even government actors openly discuss what the "correct" 
because law school education was specifically intended to be about more than just passing the NBE; MEXT regulations actually prohibit law schools from devoting too much curricular time to NBE subjects! $!^{81}$

For purposes of this article, however, the most surreal aspect of the debate over the "correct" number of hōsō is that, although commonly framed in terms of the needs of the Japanese people, it ignores a very basic reality: that a great deal of demand for legal services in Japan are met by members of other licensed legal professions that have not passed the NBE.

number of passers should be, thus illustrating that the basic function of the exam is to impose numerical limits on entrants to the elite legal professions, rather than ensure that they possess an objective minimal level of skills or knowledge. This basic reality has not stopped vast amounts of energy being devoted to the subject of what is wrong with law school education, based on the low pass rates at many schools! The MEXT had a study group looking at how to "improve law school education" that had already issued recommendations barely after the first class of law school graduates had qualified to practice. CHŪŌ KYŌIKU SHINGIKAI DAIGAKU BUNKAKAI HŌKADAIGAKUIN TOKUBETSU IINKAI, HōKADAIGAKUIN KYŌIKU NO SHITSU NO KŌJŌ NO TAME NO KAIZEN HŌSAKU Ni TSUITE (HŌKOKU), [CENTRAL EdUCATION COUNCIL, UNIVERSITY Section, Special Law School Committee, Regarding WAys of ImProving THE QUALITY OF LAW SCHOOL EDUCATION (REPORT)] (2009), available at http://www.mext.go.jp/a_menu/koutou/senmonshoku/index.htm. This body had its first meeting in March of 2008 and issued an interim report full of recommendations by September of the same year, a time at which only a single law school class (those graduating in 2006) would have only recently registered as lawyers and begun to practice of law. This indicates that the "quality" of law school education as it might be evaluated by actual users of legal services has never been a concern in the debate.

81. Senmonshokudaigakuin ni kanshi hitsuyō jikō ni tsuite sadamerū ken [Provisions for Certain Matters Necessary for Law Schools], MEXT Directive No. 53 art. 5, 2003 (Japan), available at http://www.mext.go.jp/ a_menu/koutou/houka/03050102.html. These requirements are further clarified by accrediting requirements. For example, the accrediting standards set by the National Institution for Academic Degrees and University Evaluation (NIADUE), a special administrative corporation that is one of the designated accrediting bodies, limit law schools to devoting a maximum of 54 of the minimum 93 credits required for graduation to mandatory bar exam subjects. Past and current accreditation requirements available at the NIAD-UE website. NAt'L Inst. For ACAD. Degrees \& U. Evaluation, http://www.niad.ac.jp /n_hyouka/houka/1182394_1140.html (last visited Feb. 22, 2014). 
It has long been common to compare Japan and the United States in terms of their lawyer population, with the US typically being described as having a number of lawyers one or two orders of magnitude greater than Japan - 22,000 against "more than a million"- according to a 2006 article, for example. ${ }^{82}$ Yet common-law lawyers familiar with Japan are quick to point out that the US has a unitary profession while Japan does not, rendering comparisons such as the above one of "apples $\mathrm{v}$. persimmons" (the title of one comparatively early article pointing out this basic feature of the Japanese legal system). ${ }^{83}$ At the same time, western commentators on these other professions tend to describe them with diminishing terms such as "scriveners" or "quasi-lawyers," perhaps unconsciously reflecting the condescension that in the author's experience is not uncommon when Japanese (usually those who have passed the NBE) refer to these other professions. ${ }^{84}$

\section{B. Into the Jungle: the Taxonomy of Japanese Legal Professions}

This section will give a brief description of the various licensed professions that the author believes accounts for the bulk of the legal services industry. Included are several professions that have not featured in previous western literature

82. Ian Rowley \& Kenji Hall, Japan: Lawyers Wanted. Really, BloOMBERG Bus. WK. (Mar. 22, 2006), http://www.businessweek.com/ stories/2006-03-22/japan-lawyers-wanted-dot-really; see generally David Hood, Exclusivity and the Japanese Bar: Ethics or Self-Interest?, 6 PAC. RIM L. \& POL'Y J. 199 (1997) (describing low NBE passage rate).

83. See generally Richard S. Miller, Apples v. Persimmons: The Legal Profession in Japan and the United States, 39 J. Legal Educ. 27 (1989) (describing Japanese legal education).

84. See, e.g., Masanobu Kato, The Role of Law and Lawyers in Japan and the United States, 1987 BYU L. REV. 627 (1987); Kyoko Ishida, Ethical Standards of Japanese Lawyers: Translation of the Ethics Codes for Six Categories of Legal Service Providers, 14 PAC. RIM. L. \& POL'Y J. 383 (2005); Lee Rousso, Japan's New Patent Attorney Law Breaches Barrier Between the "Legal" and "Quasi-Legal" Professions: Integrity of Japanese Patent Practice at Risk?, 10 PAC. RIM. L. \& POL'Y J. 781 (2001). 
on the subject. The decision to include a particular profession was based on a number of factors including: (1) entry to most typically involves passing a national exam with a significant legal component, (2) the services provided by the profession may also be provided by bengoshi lawyers (those who have passed the NBE), (3) some are included as rinsetsu shigyō [neighboring professions] when the other professions are mentioned in the context of the "hōsō' population problem" Since most of these professions have qualifying exams with pass rates well below $20 \%$, and some have even taken to officially referring to themselves in English as "lawyer" or "attorney ," the author (who has only passed American-style bar exams with much, much higher pass rates) will dispense with the condescending past practice of referring to them as "scriveners" or "quasi-" or "para-" anything.

\section{Bengoshi Lawyers and Other Hōsō (most judges and prosecutors).}

As already noted, the term hōsō refers to the three "elite" legal professions whose members have passed the bar exam. Passing the bar exam together with completion of the required course of training at the Supreme Court's Legal Research and Training Institute (LRTI) renders a person eligible to register as a lawyer. ${ }^{85}$ Most judges and prosecutors are chosen by the respective bureaucracies (the prosecutor's agency or the judiciary) from the eligible pool of candidates at the LRTI, with the bulk of the remainder becoming lawyers. ${ }^{86}$ Judges and prosecutors typically spend much of their career in their chosen branch of the government and, having passed the NBE and graduated from the LRTI, are entitled to register as lawyers

85. Bengoshihō [Attorney Act], Law No. 205 of 1949, art. 4 (Japan), English translation available at http://www.japaneselawtranslation.go.jp/ law/detail/?id=1878\&vm=04\&re $=02 \& n e w=1$.

86. See generally JAPANESE Ministry OF Justice, BASIC INFORMATION ON THE POPULATION OF Hōsō, available at http://www.moj.go.jp/content/ 000102262.pdf (describing differences among Japanese lawyers). 
when they reach retirement age. Thus, becoming a lawyer is itself one post-retirement option for judges and prosecutors who have passed the NBE. For purposes of the discussion that follow, however, it is important to appreciate that not all judges have passed the bar exam: it is not a requirement for Supreme Court justices and summary court judges. Neither have all prosecutors, since assistant prosecutors who have not passed the bar but passed a separate promotion exam may function as full prosecutors and even become lawyers.

Bengoshi lawyers are governed primarily by the Attorney Act. Under Article 3(1) of the act, the scope of their activities is described as being:

$[\mathrm{U}]$ pon the request of the party or the concerned parties, or upon the entrustment of public agency, shall be to engage in acts relating to lawsuits, non-contentious cases, and objections, request for re-examination, appeals, and other petitions against administrative agencies and other general legal services. ${ }^{87}$

Their relationship to the other legal professions is complicated by the fact that the "unlicensed practice of law" is defined more expansively in Article 72 of the Attorney Act as anyone but a licensed bengoshi lawyer:

[F]or the purpose of obtaining compensation, engag[ing] in the business of providing legal advice or representation, handling arbitration matters, aiding in conciliation, or providing other legal services in connection with any lawsuits, noncontentious cases, or objections, requesting for reexamination, appeals and other petitions against administrative

87. Bengoshihō [Attorney Act], Law No. 205 of 1949, art. 3(1) (Japan), English translation available at http://www.japaneselawtranslation.go.jp/law/ detail/ ?id=1878\&vm=04\&re=02\&new $=1$. 
agencies, etc., or other general legal services, or acting as an intermediary in such matters. ${ }^{88}$

Through the Attorney Act or the laws governing some of the other professions, bengoshi lawyers are also able to provide the same services as other professions. ${ }^{89}$ In one sense, therefore, bengoshi are special in that they are able to provide the broadest range of professional services. ${ }^{90}$ More importantly, however, they are the only legal profession able to represent clients in significant civil litigation as well as criminal and administrative litigation.

\section{Shihō shoshi (Judicial Scriveners/Shihoshoshi Lawyers).}

"Judicial scriveners" has been the traditional English title for this profession though such a demeaning term fails to do justice to the reality that for most of its members, joining the profession involves passing one of the most competitive law exams in the world: in 2013 it had a pass rate of just 3\%. Moreover, the profession has taken to referring to itself officially in English as "lawyers" albeit with the largely meaningless addition of the

88. Article 72 does exclude instances provided for in other laws, which is presumably the exception that allows the other professions discussed in this article to provide legal services. $I d$. art. 72 .

89. The manner in which bengoshi lawyers can provide the services open to other legal professions depends upon the statute governing the specific profession. In some cases bengoshi lawyers can simply provide the service while in others merely being a bengoshi entitles registration as a member of the other profession without satisfying any further qualifying requirements (e.g. test passage, etc.).

90. There is also a system for qualifying foreign lawyers to register with Japanese bar associations and practice as foreign legal consultants. Since the number of such professionals is few and they are not relevant to the overall subject of this article they are not discussed further. Gaikokubengoshi ni yoru hōritsu jimu no toriatsukai ni kansuru tokubetu socchihō [Act on Special Measures concerning the Handling of Legal Services by Foreign Lawyers], Law No. 66 of 1986 (Japan), English translation available at http://www.japaneselawtranslation.go.jp/law/detail/?id=1918\&vm=04\&re=02\& new $=1$. 
romanized version of their Japanese title. This comes after a brief period where they tried to refer to themselves as "solicitors" which might be the better term, given that as with solicitors in England and Wales they are similarly associated with documentation and conveyancing transactions.

Shihoshoshi lawyers also provide a wide range of other legal services, though under their enabling act they are most closely associated with professional services related to real property title-related registration and filings with the system of corporate registries, both of which are conducted at a nationwide network of hōmukyoku (Legal Affairs Bureaus), which are under the jurisdiction of the MOJ. ${ }^{91}$ They are also able to provide other services. For example, on trains it is common to see advertisements for debt-resolution services by shihoshoshi lawyers. ${ }^{92}$ On their English language web-site the Japan Federation of Shihoshoshi Lawyer's Associations indicates that their members can help buy a home, set up a company, resolve disputes with landlords, seek compensation for traffic injuries, help with employment disputes or even naturalize as a Japanese citizen. ${ }^{93}$ This seems broader than the range of services set forth in the Shihoshoshi Lawyer Act, yet doubtless reflects the realities of their practice. ${ }^{94}$ Under the Act, shihoshoshi lawyers who pass an additional certifying exam may also represent clients in small claims civil litigation in summary courts. ${ }^{95}$

91. Shihōshoshihō [Judicial Scrivener Act], Law No. 197 of 1950, art. 4 (Japan).

92. Since bengoshi lawyers also advertise the same services, it is clear that there is overlap and competition at least between these two professions. Furthermore, one can get a sense of the demographics of a particular train line from whether the advertising for such services is from bengoshi or shihoshoshi (the author has never seen advertisements from both professions on the same train).

93. See Japan Fed'n Shino-Shoshi Laws' Ass'N, http://www.shihoshoshi.or.jp/english/ (last visited Feb. 22, 2014).

94. Shihōshoshihō [Judicial Scrivener Act], Law No. 197 of 1950, art. 3 (Japan).

95. Id. 


\section{Tochikaoku Chōsashi (Land and House Investigators).}

As their name suggests, land and house investigators is a fairly specialized profession whose remit is limited to real estate transactions and the arcana of the cadastral property registration system. ${ }^{96}$ They are included for a number of reasons: they are considered "neighboring licensed professions" (rinsetsu shigyō),${ }^{97}$ the profession has roots that intersect with Shihoshoshi lawyers, ${ }^{98}$ and they now offer ADR services for boundary and other disputes involving real property. ${ }^{99}$ Furthermore, the

96. See generally JAPAN FED'N OF LAND AND House InVESTIGATORS' Ass'N, Creating Fundamental Information for National and City Planning, Protecting People's Property of Land and Buildings, and SECURING PEOPle's Rights TO PROPERTy (2006), available at http://www.chosashi.or.jp/img/outline e.pdf (describing role of Shihoshoshi lawyers). http://www.chosashi.or.jp/img/outline_e.pdf.

97. See, e.g., Ministry of Justice, Report on the Japanese Legal PROFESSION 25 (2012), available at http://www.google.com/url? sa $=\mathrm{t} \& \mathrm{rct}=\mathrm{j} \& \mathrm{q}=\& \mathrm{esrc}=\mathrm{s} \&$ source $=$ web $\& \mathrm{~cd}=4 \& \mathrm{cad}=$ rja\&ved=0CDwQFjAD\&url=http $\% 3 \mathrm{~A} \% 2 \mathrm{~F} \% 2 \mathrm{Fwww}$.moj.go.jp $\% 2 \mathrm{Fcontent} \% 2$ F000097613.pdf\&ei=Jh0XU6j0F6WbygGfmIDIBw\&usg=AFQjCNG7Z774nvt HSGRvea3NHdrdXy0bZA\&sig2=dhDmz1Tm-

T3VoNGSweiGmQ\&bvm=bv.62286460,d.aWM.

98. Historically, the profession worked with two separate property recording systems: one for title, rights and interests, another maintained for tax purposes. When these two systems were combined into the current unified system, it would have potentially resulted in a significant portion of the business of the shihōshoshi lawyers. A compromise was reached that guaranteed both professions an income under the new system. See generally NiHON SHIHŌSHOSHISHI (SENGOHEN) [POST-WAR HISTORY OF JAPANESE SHIHŌSHOSHI LAWYERS] 997-1031 (2011). An apparent byproduct of this history is a provision in the Shihōshoshi Lawyer Act which limits Shihōshoshi Lawyers to providing and advisory and non-litigation representative services relating to boundary matters involving real estate below a defined value with bigger properties being reserved to the House and Building Investigators, whose scope is unrestricted. Shihōshoshihō [Judicial Scrivener Law], Law No. 197 of 1950, art. 3(1)(viii) (Japan); see Tochikaokuchōsashihō [Land and House Investigators Act], Law No. 228 of 1950, art. 3(1)(iv) (Japan).

99. See Alternative Dispute Resolution-related Disclosure, FED'N LAND \& HOUSE INSPECTOR ASS'N, http://www.chosashi.or.jp/adr/ (last visited Feb. 22, 2014) (Japan). 
qualifying exam does involve a significant legal component, together with geometry problems that would doubtless horrify the many American lawyers who (mistakenly) went to law school to avoid math. ${ }^{100}$

\section{Gyōsei shoshi Administrative Scriveners.}

According to the Administrative Scriveners Act, members of this profession may perform the following services: (i) preparing and submitting documents for filings with government agencies, to the extent not prohibited by other laws, ${ }^{101}$ (ii) representing clients before such agencies in the filing process, (iii) preparation of contracts and documents on behalf of clients and (iv) advising clients in connection with preparing such documents. ${ }^{102}$ In reality they provide a wide range of document preparation, non-litigious representation and advisory services. ${ }^{103}$ In fact, they may even help prepare court documents for clients intending to represent themselves in family court or other civil proceedings. ${ }^{104}$ The significant potential for overlap and encroachment may explain why complaints against administrative scriveners by bengoshi lawyers for Attorney Act violations are a staple news item.

100. JAPANESE Ministry OF JUSTICE, TOCHIKAOKU CHŌSASHI [LAND AND House Investigators QuAlifying EXAM ReQuirements] § 3(2) (Japan), available at http://www.moj.go.jp/content/000110040.pdf (last visited Feb. 22, 2014).

101. Gyoseishoshihō [Administrative Scrivener Act], No. 4 of 1951, art. 1-1 (Japan) (for example, even though the Legal Affairs Bureau to which documents related to real estate transactions are filed is a "government agency," those services are reserved to Gyoseishoshi lawyers and Land and Building Investigators, so cannot be engaged in by Administrative Scriveners).

102. See generally id. arts. 1-2.

103. OSAKA GYOSEI-Shoshi LAw. Ass'N, http://www.osakagyoseishoshi.or.jp/global/english.html (last visited Feb. 22, 2014).

104. Id.

105. E.g., HP ni "kotsujiko sodan ukeru" bengoshiho ihan de gyoseishoshi ni keikokusho hyogoken bengoshi kai [Hyogō Prefecture Bar Association Sends Written Warning to Administrative Scrivener for Violating the Attorney Act by Advertising "Accepting Traffic Accident Consultations" on Home Page], MSN SANKEI (Feb. 6, 2013), http://sankei.jp.msn.com/west/west _affairs/news/130206/waf13020609310009-n1.htm (Japan). 
In 2000, the Federation of Administrative Scriveners Associations ("FASA") reportedly attempted to go the same route as judicial scriveners by adopting "gyoseishoshi lawyers" as the official English name for their profession. ${ }^{106}$ Use by the FASA of this title soon stopped however, reportedly due to pressure from the Japan Federation of Bar Associations (JFBA). ${ }^{107}$ Some administrative scriveners still use the English term "gyoseishoshi lawyer" or "administrative lawyer" or "law office" in marketing to non-Japanese clients (immigration-law related filings are the bread and butter of many members of the profession). ${ }^{108}$

In fact, because administrative scriveners perform a wide range of legal services for both Japanese and non-Japanese clients alike, many may have trouble understanding the difference between the two professions. ${ }^{109}$ This confusion is further enhanced by the fact that the Japanese terms used for bengoshi law firm (hōritsu jimushō) and administrative scrivener's office (hōmujimushō) are very similar. ${ }^{110}$ In

106. See sources cited, supra Part V.B.4.

107. Kennichi Miyahara, "Gyoseishoshi Lawyer" ko [Thinking about “Gyoseishoshi Lawyer”], EONET (Feb. 5, 2005), http://www.eonet.ne.jp/ gyoseisyoshi-m/gyoseishoshilawyer.htm.

108. Id.

109. E.g., id. (as of July 2013, the English website of the OsakaGyoseishoshi Lawyer's Association explained that Gyoseishoshi-lawyers could provide assistance in a wide variety of situations including: immigration and naturalization, incorporation, preparation of employment-related documents, numerous types of license applications and regulatory filings, preparation of wills, insurance claims, copyright, "documents to file a suit" and "various contracts").

110. "Hōritsu jimushō" literally means "law office" while "Hōmujimusho" would typically be translated "Legal affairs office." The confusion is confounded by the fact that becoming an administrative scrivener may be an option for persons who graduate from law school but are unable to pass the NBE (in an effort to prevent the build-up of an ever-increasing number of repeat takers who would inexorably drive the NBE pass rate down, law school graduates are barred by law from taking the exam more than three times). It is thus not unusual to see a Legal Affairs Office whose principal lawyer has graduated with a JD from law school (which most people associate with becoming a lawyer) but who is not actually a bengoshi. Users of legal 
Japanese, Administrative Scriveners associations sometimes advertise the profession to the public as "[y]our local law practitioner" (machi no hōritsuka).

\section{Shakaihoken rōmushi (Labor and Social Security Attorneys).}

Shakai hoken romushi are another legal profession that has been missed in some prior accounts of the legal professions despite having taken to referring themselves as "attorneys" in English. Under Article 2 of the Labor and Social Security Attorneys Act, this profession is licensed to provide a wide variety of services relating to the preparation and filing of documents relating to labor, employment, pension and other statutory benefit programs. ${ }^{111}$ Pursuant to a 2004 amendment to related laws, labor and social security attorneys who pass an additional qualifying exam may also represent clients in ADR and pretrial employment dispute proceedings, provided that if the amount in dispute exceeds a defined threshold a bengoshi lawyer must be involved as co-counsel. ${ }^{112}$

\section{Zeirishi (Certified Public Tax Accountants (attorneys)).}

Specializing in tax law, zeirishi are a type of professional who effectively straddle the border between tax lawyers and tax accountants. Although their formal English title is "certified tax accountant," individual members of the profession may refer to themselves (at least in their website URLs) as "tax lawyers" or

services would doubtless have been even more baffled if the shihoshoshi lawyers had been successful in their campaign to change the name of their profession to "homushi" (legal affairs specialist). Shihōshoshi kaimei no ugoki [Shihoshoshi Lawyers Moving to Change Their Names], AsAHI SHInBun, Apr. 19, 2008, (evening ed.), at 9.

111. Shakai hoken romushi hō [Labor and Social Security Attorney Act], Law No. 89 of 1968 (Japan).

112. Id. arts. 2(1)(i-6), 2(2). 
"tax law consultants." 113 They are considered a "legal profession" for a number of reasons. First, under the Tax Accountant Act, it is clear that they are heavily involved in advising about tax laws and the preparation and filing of taxrelated documents with taxing authorities. ${ }^{114}$ Second, they can play a role in tax litigation as a sort of "junior counsel" role to bengoshi lawyers. ${ }^{115}$ Third, licensed bengoshi lawyers may engage in the practice of a zeirishi. ${ }^{116}$ Finally, the range of services offered by zeirishi includes many that would be associated with lawyers or solicitors in other countries. According to the English website of the Japan Federation of Certified Public Tax Accountants Associations, in addition to a wide range of tax related documentation and representative activities these services include: preparing corporate and accounting documents, acting as auditors for local government authorities and acting as guardians in adult guardian proceedings. ${ }^{117}$

113. E.g., TAXLAWYER-KASHIWA, http://www.taxlawyer-kashiwa.com/ (last visited Feb. 22, 2014) (Japan) (a search of "tax lawyer" and zeirishi generate a number of professional office URLs using some combination of "taxlawyer"); TAKAHASHI-TAXLAw, http://www.takahashi-taxlaw.jp/ (last visited Feb. 22, 2014) (Japan) (an example of a member of the profession calling itself a “Tax Law Consulting” office); JAPAN FED'N OF CERTIFIED PUB. TAX ACCTS. ASS'N, http:/www.nichizeiren.or.jp/guidance/plus/interchange. html (last visited Feb. 22, 2014) (on its website the federation acknowledges that the term "tax accountant" may not adequately convey to English speakers the scope of the profession's services).

114. Zeirishihō [Tax Accountant Act], Law No. 237 of 1951, art. 2 (Japan).

115. Id. art. 2-2 (Tax Accountants may act in trials as "assistants" [hosanin] to lawyers, though their statements are considered "representative" in being treated as statements of their client or the lawyer).

116. Id. art. 3(1)(3) The fact that it is apparently possible for a bengoshi lawyer to become a zeirishi without ever cracking a book on tax or accounting helps to illustrate that the qualification requirements for at least some of the legal professions may have more to do with moderating between vested interests than protecting clients from unqualified practitioners.

117. JAPAN FED'N OF CERTIFIED PUB. TAX ACCTS. ASS'N, http://www.nichizeiren.or.jp/eng/index.html (last visited Feb. 16, 2014) (demonstrating that some firms may provide a full-range of corporate services 


\section{Benrishi (Patent Attorney).}

As the name suggests, patent attorneys are legally empowered to provide a wide range of services relating to patents and other forms of intellectual property, including not just preparation of applications and filing, but acting in a representative capacity in the preparation of licensing agreements and other contracts related to intellectual property rights. ${ }^{118}$ They may also provide ADR-related services and, since 2002, patent attorneys who have passed an additional qualifying exam may act as co-counsel with bengoshi lawyers in patent litigation. ${ }^{119}$

\section{Kaijidairishi (Marine Commission Procedure Agent/Maritime Attorney).}

Another profession that has often been left out of the description of Japan's "other" professions is the Marine Commission Procedure Agent (MCPA). Although they are something of a niche profession, they should be included nonetheless. ${ }^{120}$ Sometimes called the "shihōshoshi lawyer of the sea" (umi no shihōshoshi) or the "administrative scrivener of the sea," ${ }^{221}$ this profession may act on behalf of clients by preparing regulatory documents and filing them with government agencies under a specified range of laws relating to ships and maritime

that include corporate secretarial documentation services together with tax filings).

118. Benrishihō [Patent Attorney Act], Law No. 49 of 2000, art. 4(1) (Japan), translated in Patent Attorney Act (Apr. 26, 2000), available at http://www.jpaa.or.jp/english/aboutus/pdf/PatentAttorneyAct.pdf.

119. Id. art. 6-2(1).

120. The author first learned of the profession's existence not from any scholarship on the Japanese legal system, but because one appeared as a character in Naniwa no kinyūdō, a popular Japanese comic book about an Osaka money-lending firm.

121. See, e.g., Maritime Agency Workers, Hasegawa Law Office, http://hasegawa-office.jimdo.com/2013/01/09/\%E6\%B5\%B7\%E4\%BA\%8B\% $\mathrm{E} 4 \% \mathrm{BB} \% \mathrm{~A} 3 \% \mathrm{E} 7 \% 90 \% 86 \% \mathrm{E} 5 \% \mathrm{~A} 3 \% \mathrm{AB} /$ (last visited Feb. 5, 2014). 
personnel (including labor-related issues). ${ }^{122}$ With the decrease in number of Japanese-flagged ships, this profession is reported to be in decline. ${ }^{123}$ It is not uncommon to see a single person being qualified as both a MCPA and as an Administrative Scrivener or other profession.

\section{Tsūkanshi (Customs Broker).}

Customs brokers are included for a number of reasons. First, becoming a customs broker generally involves passing a lawbased exam. ${ }^{124}$ Furthermore, the range of services customs brokerage houses are allowed to engage in under the Customs Brokering Act clearly include what would generally be considered "legal services" - including not only preparing and filing various customs and trade related documentation, but also filing pre-trial objections to dispositions by customs authorities. ${ }^{125}$ Finally, both bengoshi lawyers and patent attorneys are exempt from the registration requirement of the Customs Brokering Act, meaning that tsūkanshi are another profession where an overlap (and competition) among professions has been anticipated. ${ }^{126}$

122. Kaijidairishihō [Marine Commission Procedure Agent Act], Law No. 32 of 1951, art. 1 (Japan).

123. This observation is based primarily on the author's discussions with a representative of the profession's trade association in 2009 , but it is also suggested by the dramatic decline in the number of Japanese seamen (from 233,700 in 1980 to 67,165 in 2011) and the dramatic decline in the number of Japanese-flagged cargo vessels having a tonnage of 2,000 tons or more from 3,016 in 1970 to 136 in 2011. The statistics are from the Japanese Shipowner's Association, http://www.jsanet.or.jp/data/data.html\#genjou (last visited Feb. 5, 2014).

124. Custom Agency Exam Description § 1.2, JAPAN Customs, http://www.customs.go.jp/tsukanshi/46 shiken/46annai.pdf.

125. Tsukanshihō [Customs Brokering Act], Law No. 122 of 1967, art. 1 (Japan).

126. Id. art. 3(5). 


\section{Kaijihosanin (Marine Tribunal Assessor).}

An obscure maritime-related legal profession is that of the kaijihosanin, who effectively acts as a lawyer before marine accident tribunals. ${ }^{127}$ Unlike the other professions discussed in this article, there is no national qualifying or selection exam to become a kaijihosanin and the profession is not governed by a specific statutory regime. Instead, they are provided for in a subsection of the Maritime Tribunal Act and subsidiary regulations. ${ }^{128}$ Eligibility to register as a kaijihosanin is based on having certain designated types of professional experience, including having certain kinds of marine qualifications, having been a magistrate (kaijishinpankan or rijikan) on a maritime tribunal, or having had experience as a teacher at various designated types of marine-related educational bodies. Bengoshi lawyers may also register as kaijihosanin, which is the principle reason for their inclusion as a category of legal qualification. ${ }^{129}$

\section{Kōshōnin (Public Notaries).}

The last profession to be discussed in this section is public notaries or kōshōnin. Kōshōnin are not like American notaries who simply verify signatures, though that is a service kōshōnin do provide. Rather, it is a very old profession based on European models, including the French Notary Rule of 1886 and also heavily influence by the system in the Netherlands. ${ }^{130}$ Kōshōnin perform a number of functions related to the commercial registry system administered by the MOJ, including authenticating the

127. See Explanation, Ministry OF LAND InFRASTRUCTURE TrANSP. \& TOURISM, http://www.mlit.go.jp/jmat/annai/ hosanin/hosanin.htm (last visited Feb. 5, 2014).

128. Kaijishinpanhō [Maritime Tribunal Act], Law No. 135 of 1947, arts. 19-23. (Japan).

129. Kaijishinpanhō shikō kisoku [Maritime Tribunal Act Implementing Regulations] Ministry of Transportation ordinance No. 8 of 1948. (Japan).

130. How to make good use of Japanese Notaries, JAPAN NAT'L NOTARIES ASs'N, http://www.koshonin.gr.jp/index2.html_(last visited Feb. 16, 2014) (listing updated English publication information). 
articles of incorporation of a new company as well as a wide range of other legal documents such as wills and promissory notes. ${ }^{131}$ Authentication of certain types of documents by a public notary results in the documents having the same effect as a confirmed court judgment. ${ }^{132}$ For example, an authenticated promissory note or other evidence of debt containing an enforcement clause can be executed directly against the debtor. ${ }^{133}$ Unlike the other professions described in this Article, public notaries are appointed by the Minister of Justice to specific notarial districts and are a special category of public servant, one whose compensation is derived exclusively from notarial fees rather than the public purse, as discussed in more detail in the next section. ${ }^{134}$ They are included in this section because as with other private sector professions, their income is derived from fees paid by private parties for legal services.

\section{Private Sector Legal Professions as a Retirement Plan}

As the preceding discussion should make clear, Japan's market for legal services is supplied by a wide variety of licensed professionals, most of whom offer a fairly narrow range of expertise and capabilities. Another way of looking at it,

131. Id.; Kokkakōmuinhō [National Public Service Act], Law No. 120 of 1947, art. 2(3)(xiii) (Japan), English translation available at MINISTRY OF JusT. (Apr. 1, 2009), http:/www.japaneselawtranslation.go.jp/law/detail/?ft=1\&re $=01 \& \mathrm{dn}=1 \& \mathrm{x}=0 \&$ $\mathrm{y}=0 \& \mathrm{co}=01 \& \mathrm{ky}=\% \mathrm{E} 5 \% 9 \mathrm{~B} \% \mathrm{BD} \% \mathrm{E} 5 \% \mathrm{AE} \% \mathrm{~B} 6 \% \mathrm{E} 5 \% 85 \% \mathrm{AC} \% \mathrm{E} 5 \% 8 \mathrm{~B} \% 99$ $\% \mathrm{E} 5 \% 93 \% \mathrm{~A} 1 \% \mathrm{E} 6 \% \mathrm{~B} 3 \% 95 \&$ page $=5$.

132. See source cited, supra note 132.

133. Minji shikkō hō [Civil Execution Act], Law No. 4 of 1979, art. 22 (Japan).

134. Kōshōninhō [Public Notaries Act], Law No. 53 of 1908, arts. 1113, 13-2 (Japan). Interestingly, despite having been amended a number of times, most recently in 2011, the Public Notaries Act has never been rewritten in modern standard Japanese as has been the case with most other Japanese statutes that were first passed in the pre-war period. Thus, despite now providing for the notarization of electronic records, it remains written in the archaic form of statutory Japanese which the average person would likely find difficult to read (perhaps that is the point!). 
however, might be to regard the multitude of licensed legal professions as a manifestation of the overall vertically-integrated nature of Japanese economic regulation. Put even more simply, most of the leading ministries essentially have their own captive legal profession - the MOJ has several, as is shown in the table that follows. The "ownership" of a particular profession can be readily identified through the ministry that has jurisdiction over the statute governing the profession.

A search for information about how to qualify for any of these professions will typically lead to the nuts and bolts of sitting for and passing the relevant exam, most of which are highly competitive. What is rarely mentioned, however, is that there is a back door into virtually all of the legal professions, with the exception of the hōso triumvirate of bengoshi lawyers, judges and prosecutors. The backdoor involves being an exbureaucrat, typically from the ministry regulating the profession. A reading of the respective governing statutes reveals that each of the non-hōsō legal professions is open to persons having requisite governmental experience. Those who qualify through this other route may either register without testing at all or receive a waiver of some or even all testing requirements. The professions thus serve as a form of amakudari.

In the interests of efficiency, the relevant information is set forth below:

\begin{tabular}{|c|c|c|c|c|}
\hline$\underline{\text { Profession }}$ & $\underline{\text { Regulator }}$ & $\begin{array}{l}\text { Testing } \\
\text { Exemption }\end{array}$ & $\frac{\text { Test Pass }}{\text { Rate }^{135}}$ & $\begin{array}{l}\text { Population } \\
\text { 2012/2013 }\end{array}$ \\
\hline Shihoshoshi Lawyer & MOJ & Yes $^{136}$ & $3 \%$ & $20,670^{137}$ \\
\hline
\end{tabular}

135. In order to avoid more citations than already appear in this table, unless otherwise noted the pass rate information for all qualifications is derived from information published on the applicable ministry website for the results of the 2012 exam for the profession indicated (all pass rates are rounded to the nearest whole percentage point).

136. Under Article 4(ii) of the Shihōshoshi Lawyer Act, persons having ten years or more experience as judicial clerks (saibanshōshokikan), judicial administrators (saibanshōjimukan), Ministry of Justice administrators (hōmujimukan) or prosecutorial administrators (kensatsu jimukan) or "other persons having equal or greater experience as designated by the MOJ" can register as shihōshoshi lawyers without passing the test if they are approved by 


\begin{tabular}{|c|c|c|c|c|}
\hline Profession & $\underline{\text { Regulator }}$ & $\begin{array}{l}\text { Testing } \\
\text { Exemption }\end{array}$ & $\frac{\text { Test Pass }}{\text { Rate }^{135}}$ & $\begin{array}{l}\text { Population } \\
2012 / 2013\end{array}$ \\
\hline $\begin{array}{l}\text { Land and Building } \\
\text { Investigator }\end{array}$ & MOJ & Yes $^{138}$ & $8 \%$ & $17,200^{139}$ \\
\hline $\begin{array}{l}\text { Administrative } \\
\text { Scrivener }\end{array}$ & MIC & Yes $^{140}$ & $9 \%{ }^{141}$ & $42,177^{142}$ \\
\hline Labor and Social & Ministry of & Yes $^{143}$ & $7 \%$ & $36,850^{144}$ \\
\hline
\end{tabular}

the Minister of Justice or the head of the local Legal Affairs Bureau, depending upon the circumstances. See sources cited supra notes 91, 93.

137. Other Membership Data Collection, JAPAN FED'N SHIHŌ-SHOSHI LAW's' AsS'NS, http://www.shiho-shoshi.or.jp/association/intro/rengoukai data.html (last visited Feb. 18, 2014) (referencing 2012 data).

138. Under Article 4(ii) of the Land and Building Investigator's Act, and Article 8 of its implementing regulations, persons having at least 10 years' relevant experience at a Legal Affairs Bureau and demonstrating adequate knowledge are eligible to register without testing. Tochikaokuchōsashihō [Land and House Investigators Act], Law No. 228 of 1950, art. 4(ii) (Japan).

139. Message from the Chairman, JAPAN FED'N OF LAND AND House INVESTIGATOR's Ass'NS, http://www.chosashi.or.jp/gaiyou/message.html (last visited Feb. 14, 2014) (approximate number for 2013, according to industry federation website).

140. In addition to allowing bengoshi lawyers, patent attorneys, chartered accountants and certified public tax accountants to register as administrative scriveners without testing, the Administrative Scriveners Act accords a similar privilege to a wide range of persons who have 20 years or more experience in a variety of public service positions (only 17 years for high school graduates) without taking any exam. Gyōseishoshihō [Administrative Scrivener Act], No. 4 of 1951, arts. 2, 6 (Japan).

141. Judicial Scrivener Test Result List, JAPAN FED'N ADMIN. SCRIVENERS, http://gyosei-shiken.or.jp/gokaku/ichiran.htm (last visited Mar. 31,2014 ) (Pass rate data is from website of the foundation that administers the exam).

142. Japan Fed'n Certified Admin. Procedures legal Specialist Ass'NS, http://www.gyosei.or.jp/information/unit/membership.html (last visited Feb. 18, 2014).

143. The Labor and Social Security Attorney Act requires persons seeking to qualify for the profession to pass an exam on specified areas of law and also includes an attachment exempting persons having the requisite amount of experience (typically 5, 10 or 15 years) in employment, labor and benefitsrelated roles in national or local government agencies. Arts. 3, 9, 11, Schedule 2. The Act specifically envisions that some persons will be exempted from all subjects and be eligible to join the provision without testing. Art. 3(1)(ii). Bengoshi lawyers are also eligible for registering without testing. Art. 3 (2).

144. JAPAN FED'N LABOR \& SOCIAL SECURITY ATT'YS' ASS'NS, http://www.shakaihokenroumushi.jp/index.html (last visited Feb. 14, 2014). 


\begin{tabular}{|l|l|l|l|l|}
\hline Profession & $\underline{\text { Regulator }}$ & $\frac{\text { Testing }}{\text { Exemption }}$ & $\frac{\underline{\text { Test Pass }}^{135}}{\text { Recurity Attorney }^{\text {Health Welfare }}}$ & $\begin{array}{l}\text { Population } \\
\text { \& Labor }\end{array}$ \\
\hline $\begin{array}{l}\text { Certified Public Tax } \\
\text { Accountant }\end{array}$ & $\begin{array}{l}\text { Ministry of } \\
\text { Finance } \\
\text { (National Tax } \\
\text { Agency) }\end{array}$ & Yes $^{145}$ & $18 \%{ }^{146}$ & $73,524^{147}$ \\
\hline Patent Attorney & $\begin{array}{l}\text { METI (Patent } \\
\text { Agency) }\end{array}$ & Yes ${ }^{148}$ & $6 \%$ & $10,128^{149}$ \\
\hline
\end{tabular}

145. Certified Public Tax Accountant is the most open of the legal professions, which may explain why it is also has the most members. Zeirishihō [Certified Public Tax Accountants Act], Law No. 99 of 2007, arts. 3(1)(ii), 7, 8 (Japan) (these articles establish a broad range of exemptions from the testing requirement for persons who have done academic research or have 10 or 15 or more years of experience in a wide range of tax-related government jobs.) The Act specifically envisions that some persons will register based on an exemption of all subjects tested on the exam. Id.

146. $18 \%$ is the national average which does not take into account the various exemptions available for certain tested subjects. The average pass rate taking into all subjects actually tested was 15\%. Fiscal Year 2012 (62nd) Tax Accountant Test Results, NAT'L TAX AGENCY, http://www.nta.go.jp/sonota/ zeirishi/zeirishishiken/shikenkekka2012/01.htm (last visited Feb. 18, 2014).

147. JaPAn FeD'N Certified Public TaX ACCTS' Ass'NS, 2013 data from http://www.nichizeiren.or.jp/guidance/intro/registrant.html (last visited Feb. 18, 2014) (providing data from 2013).

148. Under Article 7 of the Patent Attorney Act, bengoshi lawyers are qualified to be patent attorneys without having to pass the qualifying exam, as are persons who have "engaged in the trial or examination affairs as a trial examiner or examiner at the Japan Patent Office for a total of seven or more years." Benrishihō [Patent Attorney Act], Law No. 49 of 2000, art. 7 (Japan), English translation available at Patent Attorney Act (Apr. 26, 2000), http://www.jpaa.or.jp/english/aboutus/pdf/PatentAttorneyAct.pdf.

149. JAPAN PATENT ATT'Y ASS'N, http://www.jpaa.or.jp/ (last visited Feb. 19, 2014) (providing data from 2013). 


\begin{tabular}{|c|c|c|c|c|}
\hline Profession & $\underline{\text { Regulator }}$ & $\begin{array}{l}\text { Testing } \\
\text { Exemption } \\
\end{array}$ & $\frac{\text { Test Pass }}{\text { Rate }^{135}}$ & $\begin{array}{l}\text { Population } \\
\text { 2012/2013 } \\
\end{array}$ \\
\hline $\begin{array}{l}\text { Marine Procedure } \\
\text { Commission Agent }\end{array}$ & $\begin{array}{l}\text { Minister of } \\
\text { Land } \\
\text { Infrastructure } \\
\text { Transportation } \\
\text { and Tourism }\end{array}$ & Yes $^{150}$ & $50 \%{ }^{151}$ & $\begin{array}{l}\text { At least } 345 \\
+{ }^{152}\end{array}$ \\
\hline Customs Broker & $\begin{array}{l}\text { Ministry of } \\
\text { Finance } \\
\text { (National Tax } \\
\text { Agency) }\end{array}$ & Partial $^{153}$ & $7 \%$ & $7,366^{154}$ \\
\hline
\end{tabular}

150. Persons having at least 10 years government experience deemed suitable by the Minister of Land Infrastructure Transportation and Tourism may register without the exam. Kaijidairishihō [Marine Commission Procedure Agent Act], Law No. 32 of 1951, art. 2(ii) (Japan).

151. KAIJ AGENCY ATT'YS' Ass'N, http://jmpcaa.org/main/24-5.php (last visited Feb. 14, 2014).

152. The number given is that of members of the Marine Procedures Commission Agent Association for 2013 as disclosed on the association's website. Notice of Membership List Update, KAJI AGENCY ATT'Ys' Ass'N, http://jmpcaa.org/main/300/post-21.php (last visited Feb. 16, 2014). Unlike most of the other professions for which it is mandatory to be a member of a prefectural professional association, marine procedures commission agents are not subject to such a requirement, meaning association membership data does not reflect the entire population.

153. The customs broker qualifying exam tests knowledge of customs, tariff and other trade-related statutes, the preparation of customs-related documents and the Customs Brokering Act itself. Tsukanshihō [Customs Brokering Act], Law No. 122 of 1967, art. 23(2) (Japan). Persons having 15 or more years' experience in a customs-brokering related job or related government experience need only pass the test on the Act itself while those with 5 or more years' experience are exempted from the "practical" (documentation preparation) component of the exam. Id. art. 24(i)-(ii).

154. The 2013 data is available on the Japan Customs website. Current Status of the 8101 Customs Officer, JAPAN CuSTOMS, http://www.customs.go. jp/tetsuzuki/c-answer/shiken/8101_jr.htm (last visited Mar. 31, 2014). 


\begin{tabular}{|l|l|l|l|l|}
\hline Profession & $\underline{\text { Regulator }}$ & $\begin{array}{l}\text { Testing } \\
\text { Exemption }\end{array}$ & $\frac{\underline{\text { Rest Pass }}^{135}}{\text { Kaijihosanin }^{\text {Manistry of }}}$ & $\begin{array}{l}\text { Population } \\
\mathbf{2 0 1 2 / 2 0 1 3}\end{array}$ \\
\hline $\begin{array}{l}\text { Land } \\
\text { Infrastructure } \\
\begin{array}{l}\text { Transportation } \\
\text { and Tourism }\end{array}\end{array}$ & No test ${ }^{155}$ & $\mathrm{n} / \mathrm{a}$ & $\begin{array}{l}\text { Approx. } \\
1,000 ?^{156}\end{array}$ \\
\hline Public Notary & MOJ & Yes, but no & $\mathrm{n} / \mathrm{a}$ & Approx. 500 \\
\hline Bengoshi Lawyer & None & No & $25 \%$ & $35,105^{159}$ \\
\hline
\end{tabular}

155. There is no test for this profession, but those eligible to register for it include persons with experience as maritime tribunal magistrates. Eligibility for those positions includes persons with clearly defined degrees of maritimerelated public service experience. Kaijishinpanhō shikorei [Marine Tribunal Act Implementation Ordinance], Cabinet Ordinance No. 54 of 1948, art. 2 (Japan); Kaijishinpanhō kisoku [Marine Tribunal Act Implementing Regulations], art. 19(ii) (Japan).

156. Recent numbers have not proved readily available, and there is no professional federation. A publication on the MLIT website gives the number of registered Kaijihosanin as of the end of 2000 as 1,078 (a number that includes 418 bengoshi lawyers). Marine Accident Report, MinISTRY OF LAND, INFRASTRUCTURE, \& TOURISM, available at http://www.mlit.go.jp/jtsb/kai/ genkyou/report top.html.

157. Technically there are two ways of becoming a bengoshi lawyer without having passed the NBE. The first is to have been a justice on the Supreme Court of Japan (for which NBE passage is not a formal prerequisite). Bengoshi Hō [Attorney Act], Law No. 205 of 1949, art. 6. (Japan). The second is to have been an assistant prosecutor (fukukenji - a category of prosecution agency official who has not passed the NBE) who passes an exam qualifying them to become a prosecutor (kensatsukan). Although most prosecutors have passed the NBE, the Attorneys Act allows prosecutors who have qualified in this fashion and have worked for at least five years as full prosecutors are eligible to register as bengoshi lawyers. Id. art. 5(3)(iii); Kensatsuchohō [Prosecutors Act], Law No. 61 of 1947, art. 18(3) (Japan).

158. Pass rate is derived from information published on the website of the Ministry of Justice, which administers the NBE. The Results of the Bar Exam 2012, MinISTRY OF JUSTICE, http://www.moj.go.jp/jinji/shihoushiken/ jinji08_00063.html (last visited Feb. 16, 2014).

159. The 2013 data is available on the Japan Federation of Bar Associations website. Member of the Japan Federation of Bar Associations, JFBA, http://www.nichibenren.or.jp/jfba_info/membership/about.html (last visited Mar. 1, 2014). 
The following information from formal responses to written inquiries made by the author to some of the relevant professional federations in 2010 is indicative. In 2009 1,511 people newly registered as administrative scriveners based on passing the exam while 613 did so based on government experience. In the same year, 895 persons registered as Gyoseishoshi lawyers based on exam passage while 130 did so through approval based on government experience. Similarly, of the 8,608 total number of patent attorneys registered as of April 30, 2010, 633 had done so based on patent agency experience compared to 7,759 who did so after passing the exam. As of March 31, 2010, 8,630 of the certified tax accountants registered at the time (over $10 \%$ of the total) qualified through based on government tax administration experience rather than test passage or other means. Of the 2,642 newly registered zeirishi in 2009, 864 registered based on government experience rather than testing. ${ }^{160}$

Thus, although the numbers are generally not large compared to the total for each profession, they still represent a significant amakudari component in each profession queried. If only one or two amakudari board members can potentially change the corporate governance dynamic of a company or the role played by a foundation, the fact that each legal profession represents a vested interest of its supervising ministry means that the numbers do not necessarily need to be large to influence the way the various qualifying systems are operated and interact with each other. ${ }^{161}$

160. Responses on file with author.

161. A similar comment should be made about the process of qualifying as a Bengoshi lawyer, which generally requires completion of a course of training at the LRTI which is best thought of as a judicial/legal bureaucrat training institute even though the majority of people who pass through it become lawyers, some of whom may wish to become business lawyers rather than litigators and thus not need the courtroom-focused training and testing regime provided at the LRTI (a regime which makes more sense if it is intended primarily for those trainees who will spend much of their career in court: future judges and prosecutors). Here it is also worth noting a recent book on professional qualifications which asserts that although only a minority of zeirishi tax accountants are Tax Agency OBs, those which are can retain clients 
This reality may be one of the underlying reasons why, despite usually being framed in terms of demand for legal services and the quality thereof, the debate over the "hōsō population problem" is typically conducted without reference to the much larger population of other types of service providers. ${ }^{162}$ It would probably be politically impossible to have a meaningful discussion of the Japanese legal services industry as a whole, even though that would be the format that reflected the actual needs of the Japanese people. Such a debate would almost certainly be impossible because it would involve too many vested interests and bureaucratic stakeholders. ${ }^{163}$

From the standpoint of bureaucratic institutions, it is doubtless much simpler for each ministry to have its own profession, thereby limiting the number of stakeholders involved in its administration as well as opportunities for inter-agency conflict to arise. On a very basic level, the law school system developing into the policy disaster it is widely acknowledged to

not just through good service but through the (possibly unfounded) fear on the part of their clients that changing to a different firm will trigger a tax audit. If this is true, the tacit threat of an audit would rely primarily on the tax accountant's government connections. SATŌ RUMI, SHIKAKU WO TORU TO BINBŌ NI NARIMASU [ACQUiRING QuALIFICATIONS MAKE YOU PoOR] 120-22 (2014) (Japan).

162. Interestingly, a June 2013 LDP investigatory committee report relating to the law school system includes shihōshoshi lawyers and labor and social security attorneys as hōsō in its discussion of the problem because of their ability to represent clients in certain legal proceedings, but does so as part of a discourse on why there are too many hōsō as it is. See generally Jiyūminshutō seimu chōsakai - shihōseidō chōsakai, Hōsō yōseiseido ni tsuite no chūkan teigen [Interim Recommendations on the System for Training Legal Professionals], June 18, 2013, available at. http://www.moj.go.jp/content/000111842.pdf.

163. In what the author considers to be one of the most insightful books on reforms to the hōsō legal professions and the law school system, bengoshi lawyer Masahiro Kobayashi relates an incident at one of the consultative committee meetings where law schools were being discussed where one member tried to broaden the discussion to include the neighboring professions, but was told that it was unnecessary to discuss the subject and it would make the focus too broad. MasahiRo Kobayashi, KonNA NICHIBENREN NI DARE GA SHITA? [WHO MADE THE JFBA THIS WAY?] 202 (2012). 
be can probably be attributed to it involving too many overlapping jurisdictions and interests. These include the MEXT, which regulates universities and was able to acquire a new jurisdictional mandate out of the process - regulating graduate legal education, ${ }^{164}$ the MOJ, which retains control over the entry to the hōso professions through its administration of the NBE, ${ }^{165}$ and the JFBA and prefectural bar associations, which are unregulated by any Ministry yet whose members have a vested interest in limiting competition. The essential problem faced by the law school system - too many law graduates (because the MEXT licensed too many law schools) sitting for not enough passing slots on the NBE - could thus be attributed in part to poor inter-agency cooperation. Adding more legal professions and thus more ministries to the mix would probably be even more disastrous. The term "hōsō population problem" thus describes the debate from the standpoint of the various vested interests involved rather than the population of actual or potential users of legal services. It does not describe any problem in the overall population of legal service providers in general, since apparently one does not exist. Indeed, the debate is taking place at a time when many of the non-hōsō legal professions are both increasing in numbers and expanding the scope of the services they provide, including into low-level litigation and ADR services, as already described. ${ }^{166}$ These developments go

164. Somewhat bizarrely, around the same time the law school system began operations, the Ministry of Justice assumed responsibility for preparing materials for teaching children in junior high and high school about law. Promotion and Development of Law-Related Education, MinISTRY OF JUSTICE, http://www.moj.go.jp/ENGLISH/issues/issues10.html (lasted visited Feb. 23, 2014). The author suspects that it was part of whatever inter-agency tradeoffs were involved in allowing the MEXT to assume control of educating the elite legal professions!

165. One could include the Supreme Court as a gatekeeper also, since it controls the LRTI, graduation from which is a prerequisite to becoming a hōsō.

166. An on-line guide to the Law School Equivalency Exam published by the test-tutoring academy Tokyo Legal Mind (LEC) shows increases in most of the other professions during the period from 2004 (when law schools started operations) to 2011. Shihōshoshi lawyers went from 17,667 to 20,313 (with those licensed to represent clients in summary court doubling from 6,351 to 
almost completely unnoticed in the mainstream media, which only seems to be interested in the sudden excess of bengoshi lawyers.

While the media frequently uses terms such as the "hōsō population problem" or the "bengoshi population problem ," no other providers of legal services seem to suffer from such a problem. ${ }^{167}$ One reason might be that while the NBE acts as an absolute control on the number of people able to qualify as lawyers, necessitating that the "problem" be debated in conjunction with law schools and their educational quality as measured by bar performance. By contrast, while the exams for the various other legal professions are highly competitive - each having a pass rate well below that of the bar exam of any US jurisdiction - they do not provide the same role as a "population control device ," since no matter the pass rate on the exam, qualifying ex-bureaucrats can always join.

There is also an important difference in the way the legal professions are regulated. While most of the various professions have prefectural associations and a national federation, they are also ultimately subject to regulation (including sanctions for

13,258 ), administrative scriveners increased from 37,607 to 41,584 , labor and social security attorneys went from 27,926 to 35,864 , patent attorneys went from 5,654 to 8,684 (with those qualified to represent clients in litigation going from 496 to 2,563) and certified tax accountants increased from 67,370 to 72,039 . The growth in these populations compares to an increase in the number of lawyers from 17,667 to 20,313 over the same period. Rinsetsu shigyō to no gyōsai [Overlapping Professional Areas], ToKyo Legal Mind 2 (2012), available at http://www.lec-jp.com/yobi_shiken/pdf/about/frontline/2012/ frontline03.pdf.

167. By way of example, a Google search conducted on August 1, 2013 for "hōsō jinkō mondai" (Hōsō population problem) generated 145,000 hits. A search for "bengoshi jinkō mondai" (Bengoshi lawyer population problem) revealed 26,800 hits. Similar searches in Japanese for "Shihōshoshi lawyer problem," "Administrative lawyer problem," "Labor and Social security attorney problem," "Patent lawyer population problem," and "Certified tax accountant population problem" generated seven, zero, zero and zero hits, respectively. 
misconduct) through their supervising Ministry. ${ }^{168}$ Bengoshi lawyers are the exception, being the only legal profession that is truly self-regulating and independent of the government, including in connection with the process of disciplining its members. ${ }^{169}$ While other professions have what might be called "bar associations" with professional rules of conduct, those rules do not have the same level of import as the Japanese bar rules of professional conduct, since bengoshi create their own disciplinary rules and are also independent of the government. As noted by Ishida in her discussion of the rules of ethics for five of the non-bengoshi professions, they "are disciplined by

168. Shihōshōshi lawyers and Land and Building Investigators are subject to sanctions by the head of the local Legal Affairs Bureau. Gyōseishoshihō [Administrative Scrivener Act], No. 4 of 1951, art. 47 (Japan);Tochikaokuchōsashihō [Land and House Investigators Act], Law No. 228 of 1950, arts. 42-46 (Japan). Administrative Scriveners are subject to oversight by and sanctions from the governor of the prefecture in which they are registered (jurisdiction over political subdivisions falls under the jurisdiction of the Ministry of Internal Affairs and Communications). Administrative Scrivener Act, arts. 13-(22)-14-(5). Labor and Social Security Attorneys are subject to the Ministry of Health, Labor and Welfare. Shakai hokenrōmushihō [Labor and Social Security Attorney Act], Law No. 89 of 1968 (Japan), arts. 24-25-5. Certified Tax Accountants are subject to sanction by the Minister of Finance. Zeirishihō [Certified Public Tax Accountants Act], No. 237 of 1951, arts. 44-48. (Japan). Marine Procedures Commission Agents are subject to sanctions from the head of the applicable Regional Transportation Bureau. Kaijidairishihō [Marine Commission Procedure Agent Act], Law No. 32 of 1951, art. 25 (Japan). Customs brokers may be sanctioned by the Head of Customs. Tsūkanshihō [Customs Brokering Act], Law No. 122 of 1967, art. 35 (Japan). Note that the degree of regulation even extends to corporate governance: for example, under Article 25-22-2(3) and (4), the Minister of Health, Labor and Welfare may express "opinions" in court proceedings relating to the dissolution of a Labor and Social Securities Act professional services corporation. Id. art. 25-22-2(3), (4). The question of whether such opinions (e.g. "dissolution should not be allowed) are binding on the court, and whether their issuance constitute administrative action subject to challenge under the Administrative Procedure Act does not appear to have addressed.

169. Under the Japanese constitution the Supreme Court has the authority to make rules governing lawyers, though it has not done so. NiHONKOKU KENPō [KenPō] [CONSTITUTION], art. 77 (Japan). 
specific government agencies under applicable laws. Their ethics codes are merely aspirational."170

Thus, to ask whether the law school system and the increase in bengoshi lawyers will result in Japanese law and culture becoming further "Americanized" (as a 2006 article on the subject does) requires ignoring the reality that the Japanese legal services industry as a whole is structured in a way which both facilitates amakudari and ensures that the preponderance of needs for such services are met by providers who are inherently incapable of doing so in an adversarial way, particularly vis-à-vis the relationship between legal profession and government. ${ }^{171}$

After taking into account the extensive range of services offered by non-bengoshi legal professions, services that include representation and other services relating to low-level civil litigation, it is worth taking stock of what is so special about bengoshi lawyers. Certainly, they may provide a much broader range of services than the other professions. Yet on another level, their real significance may be that they are both independent of the government and are also the only profession vested with the power to stand between the government and the people, as criminal defense lawyers or in administrative or constitutional litigation. It is thus indeed interesting that bengoshi lawyers are the only profession about whom there is a heated debate over how few of them there should be. ${ }^{172}$ Yet if

170. Ishida, supra note 84, at 385. An additional level of ministryspecific regulation is also established through rules governing professional service corporations, with most of the professions having specific rules for the special types of corporations through which each profession may provide services. For example, the Labor and Social Security Lawyer Act includes a section providing for Labor and Social Security Lawyer Corporations, the Administrative Scrivener Act provides for Administrative Scrivener Corporations and so forth.

171. Schumann, supra note 77 , at 519.

172. See Hood, supra note 82, at 202. As noted by David Hood in his 1997 article, "only the interests of the state bureaucracy and the major corporations are served by the small size of the bar." $I d$. at 211 . This statement probably remains true despite the "dramatic" increase in the number of bengoshi lawyers since the start of the law school system, given that even at 
one looks at the other legal professions as forming part of an overall system of amakudari that "provides channels of communication that increase the stability and effectiveness of state policy," $" 173$ there is a certain logic to only paying attention to the one profession that can be both disruptive and directly oppose state action in court.

\section{The Legal Professions as a Source of Indirect Amakudari}

In any case, such debate as does take place about the legal professions does so within the context of a highly balkanized legal profession in which amakudari seems to be an almost invisible yet omnipresent feature. In fact, one can find the influence of amakudari in the process of qualifying for some of the professions themselves. For example, the administrative scrivener exam - a national exam provided for by statute - is administered by the Administrative Scrivener Exam Center, a foundation. ${ }^{174}$ While its website suggests that it is simply a private foundation, it is considered an amakudari destination and when the author first examined the web site a few years ago it listed three directors who were formerly MIC bureaucrats. ${ }^{175}$

Similarly, the professional associations themselves may also employ retired ministry officials. The federations of administrative scriveners, public notaries, a number of prefectural shihoshoshi lawyers and land and house investigator associations, and the Japan Patent Attorneys Association have all

over 30,000 their numbers remain small both in comparison to the other legal professions and the population as a whole.

173. COLIGNON \& UsUi, supra note 2, at 113.

174. JAPAN FED'N ADMIN. SCRIVENERS, http://gyosei-shiken.or.jp/ (last visited Feb. 23, 2014).

175. The site has since taken to just listing the names of the directors, with no other biographical details, a practice that seems to becoming increasingly common with such organizations! Having been researching such foundations for several years, the author can attest that the ability to obtain information on the backgrounds of their directors has declined markedly just over the past few years. 
been identified as institutions whose boards include ministry OB. ${ }^{176}$

The law school system itself is also structured to ensure amakudari opportunities: MEXT regulations require that at least $30 \%$ of a law school's full-time faculty have five or more years' experience in practice. ${ }^{177}$ While this may include lawyers (and even a few non-hōsō), retiring judges and prosecutors are natural candidates, particularly at private law schools that are likely to have a later retirement age than public ones. ${ }^{178}$ Of course experienced judges and prosecutors may well be valuable additions to a law school faculty and many law schools might choose to hire some of them anyways. The point is that embedding a requirement in regulations effectively ensures that there will be a steady supply of law school jobs for which exjudges and prosecutors are eligible. ${ }^{179}$

176. ICHIIMURA, supra note 21, at 125, 127-33, 147, 297.

177. Matter to Provide for the Matters Necessary for the Professional Graduate School, Notice No. 53 of 2003, art. 2 [hereinafter MEXT Notice No. 53], available at http://www.mext.go.jp/a_menu/koutou/houka/03050102.htm (Japan). Note that prior to the start of the law school system, law in Japan was a primarily academic discipline taught at undergraduate faculties, with those wishing to become scholars going on to pursue higher education in graduate programs without passing or even sitting for the NBE. The majority of Japanese law professors are not qualified as lawyers and would thus not count towards satisfying the practice experience requirement.

178. The author qualifies as a non-hōsō practitioner faculty member at his law school. By way of example, when reviewed on August 1, 2103, the web-site of Yamanashi Gakuin Law School (Yamanashi University is a private university) listed 15 full-time faculty members. Of these, eight were listed as "practitioners" and included two former judges and two former prosecutors. Yamanashi Gakuin Educational Foundation, YAMANASHI GAKUIN SCHOOL OF LAw, http://www.ygu.ac.jp/yggs/houka/staff/staffl.html (last visited Aug. 1, 2013).

179. The guarantee created by the regulations being apparently more important than the academic freedom supposedly guaranteed by Article 23 of the Japanese Constitution. NiHONKOKU KENPŌ [KENPŌ] [CONSTITUTION], art. 23 (Japan). 


\section{E. New Legal Professions - the More the Merrier?}

How to expand the scope of activities of the "excess" population of bengoshi lawyers beyond the profession's traditional realm of courtroom litigation is currently a subject of serious debate within policy circles. ${ }^{180}$ However, a basic problem in such expansion would seem to be that in a world where there are already multiple legal professions, the barriers to creating new ones before lawyers can occupy a particular legal services "space" may not be very high.

For example, one might consider adding the tochi kairyō kanchishi [land improvement and re-plotting specialist]. This obscure profession offers opinions regarding plans for accumulating and combining agricultural land. ${ }^{181}$ Its existence is

180. See, e.g., "Hōsō yosei seido kaigi - chukan torimatome" [Interim Points of Meetings to Consider Legal Profession [hoso] Training], Special Law School Working Group OF MEXT's Central EduCATion, Culture, SPORTS, SCIENCE AND TECHNOLOGY: JAPAN, http:/www.mext.go.jp/b_menu/ shingi/chukyo/chukyo4/012/siryo/attach/1335288 (last visited on May 8, 2013). The Interim Points cover three principle subjects, one of which was how to expand the fields in which lawyers could practice. The possibilities for expansion discussed carefully avoid the areas covered by other legal professions and focus on lawyers: (i) joining more corporate legal departments (though corporate Japan was largely ignored as possible employers early in the law school development process), (ii) becoming public servants, (iii) working more with the Japanese legal aid system, (iv) working more with ex-convicts after their release from prison and (v) lawyers becoming more involved in the overseas business of Japanese companies. (iii) and (iv) are interesting because both are under the control of the MOJ, and may have been suggested because the MOJ is a stakeholder already involved in the process that might be able to help find more jobs for lawyers. (v) is interesting because even though it effectively involves lawyers to commit what in other countries might be considered malpractice - the unlicensed practice of foreign law - it is likely a valid option because there are no vested interests to offend by expanding into this domain. The fact that the demands of the NBE - which is focused exclusively on domestic law (and mostly litigation-related subjects) - now make it difficult to engage law students in classes relevant to international business (as the author can attest from personal experience) is apparently not a concern. Id.

181. See generally Rural Dev. Bureau Ministry of Agric., Forestry and Fisheries Motor Serv. DeP'T Land Improvement Planning Div., 25 
made necessary by the Land Improvement Act (LIA), a statute administered by the Ministry of Agriculture, Forestry and Fisheries (MAFF). ${ }^{182}$ The LIA is aimed at increasing farm productivity through the rationalization of agricultural land usage, a complex process that can involve the rights of numerous owners and users of farmland, a special type of property that is itself subject to a byzantine regulatory regime. Under Article 52(4) of the LIA, before a land rationalization plan can be approved the opinion must be sought of a person "having expert knowledge relating to the aggregation of agricultural land and practical experience in such activities, as specified by Cabinet Order."

The cabinet order in question delegates to MAFF the authority to establish a qualifying exam for the qualification, which is only named in this lowest level of regulation. ${ }^{183}$ The test is held annually and consists of two components. The first is the law portion, which requires knowledge of the LIA, the Civil Code, the Agricultural Land Act, the Family Registry Act, recording statutes and other relevant laws and regulations. ${ }^{184}$ The second is a practical skills test on subjects such as formulating an aggregation plan and researching land title records. ${ }^{185}$ The practical skills portion of the test is waived for persons having at least ten years practical experience, indicating the qualification is likely an option for retiring agricultural officials. ${ }^{186}$

YeAr LAND ImProvement Allocated LAND Qualification TeSt, available at http://www.maff.go.jp/j/nousin/kikaku/kantisi/pdf/25annai.pdf.

182. Tochi kairyō hō [Land Improvement Act], Law No. 75 of 1949 (Japan).

183. Tochikairyōhō shikō rei [Land Improvement Act Implementing Order], Cabinet Order No. 295 of 1949, art. 44-4, (Japan); Tochikairyōhō shikō kisoku [Land Improvement Act Implementing Regulations], MAFF Order No. 75 of 1949 (Japan).

184. See sources cited, supra note 161.

185. Id.

186. See MAFF 2013 EXAM NotICE, MAFF, http://www.maff.go.jp/j/nousin/kikaku/kantisi/pdf/25annai.pdf (last visited Mar. 31, 2014), for test content and eligibility requirements. The notice is careful to make clear that "permitting and guidance" (i.e., administrative functions) is included in qualifying for the waiver of the practical skills portion 
Agricultural land rationalization is a complex subject and having a special qualification for those who provide related advisory services may be a perfectly logical solution. The point is that understanding and mediating the legal issues involved is something that bengoshi lawyers could do as well, yet the existence of a more specific qualification in the field is likely to act as a disincentive to at least some who might otherwise seek to specialize. Furthermore, the ability of ministries to create new professions that provide a type of legal service would seem to limit the ability of existing professionals to branch out into new areas of specialization.

\section{F. Amakudari and the Law; Another Look at Public Notaries}

The example of the tochi kairyōshi shows how the law can subtly be used to make the involvement of a specific profession a mandatory part of certain economic transactions. Since agricultural land aggregation is an esoteric subject, it may help to offer an example in the field of corporate law by taking another look at public notaries.

Public notaries are appointed by the Minister of Justice to serve at specific Public Notary Offices (kōshō yakuba) around the country, with each office corresponding to the location of the regional Legal Affairs Bureaus (hōmukyoku) where real estate title and corporate registries are. ${ }^{187}$ Article 12(1) of the Public

of the test. Here, some might point out that that retired bureaucrats would still have to demonstrate an adequate knowledge of the relevant law, which is true. At the same time, it is worth bearing in mind that just as with the NBE itself, many national exams exist essentially for the purpose of failing most takers rather than passing those who demonstrate an objective level of knowledge or skill. See Colin P.A. Jones, Stop thinking - the test is about to start, THE JAPAN TIMES, Dec. 18, 2012, http://www.japantimes.co.jp/community/2012/12/18/

issues/stop-thinking-the-test-is-about-to-start/\#.Ujextj-9Xg4. For obscure qualifying exams such as this, that it is used to create the appearance of openness while at the same time limiting entry to insiders is a possibility that should be considered. See also MEXT notice no. 53, supra note 179.

187. Kōshōninhō [Public Notaries Act], Law No. 53 of 1908, art. 11 (Japan). 
Notary Act defines eligibility for appointment as a public notary primarily in negative terms: those who are not Japanese and who have not passed the qualifying exam and completed a six month apprenticeship are not eligible. Article 12(2) delegates the details of implementing the notarial exam and the apprenticeship to the Minister of Justice. Article 13 of the Act specifies that Judges (excluding summary court judges), prosecutors (excluding assistant prosecutors) and lawyers do not have to pass the notarial exam or go through an apprenticeship to be eligible for appointment. Article 13-2 also allows as a "temporary measure" the appointment of other "persons of learning" as notaries without a test or apprenticeship. ${ }^{188}$

Although the regime clearly envisions an exam from which the stated categories of persons are exempt, the notary exam called for in Article 12 of the Act has apparently not been held for over a century: public notary appointments are essentially reserved exclusively as post-retirement jobs for judges, prosecutors and, thanks to the "temporary" measure in Article 13-2 of the Act, other ex MOJ and judicial personnel. According to a report compiled in 2004 by the Japan Federation of Bar Associations (the "JFB"), in 2002 there were 462 public notaries. Of these, 131 were former judges, 204 former prosecutors, 110 former Legal Affairs Bureau (i.e., MOJ) personnel, 13 were former prosecutorial staff and 3 former judicial clerks. ${ }^{189}$

The MOJ is the regulator of the notarial system and has jurisdiction over the Public Notarial Act, yet seems almost coy when it comes to providing information about it. The MOJ gives

188. Id. art. 13-2. In addition to the formal requirements set forth in the law, some sources still refer to notaries being chosen from persons having at least 30 years practice experience, an additional requirement which would clearly render the position an amakudari position! See Please Tell Us About the Notary Office, NisHOINOMIYA CiTY (Mar. 23, 2012), http://www.nishi.or.jp/ contents/00011167000200007.html.

189. Japan Fed'n Bar Ass'ns, Public Notary Report, Ass'N OF Victims OF Wills AND NotARIZED DeEDS, http://yuigon.us/german.html (last visited Feb. 23, 2014) [hereinafter Public Notary Report]. 
the total population of public notaries as "about" $500 .{ }^{190}$ Since 2002 the MOJ has issued public announcements regarding notary position vacancies, though this likely nothing more than window dressing. ${ }^{191}$ For example, the most recent advertisement by the MOJ for Article 13 applicants was officially posted for only two weeks, with applications being accepted during a one-week window. ${ }^{192}$ The MOJ announcement on Article 13-2 applicants also reveals similarly short periods in which applicants with suitable experience in public service positions in courts, the MOJ or prosecutorial jobs may apply. ${ }^{193}$ The process also involves a written test (if there is more than one applicant for a position) as well as an oral exam. ${ }^{194}$

190. Letter from Federation of Public Notaries to author (2010) (on file with author) (claiming that there were 498 public notaries as of May 6, 2010).

191. In May of 2010 the author found on the MOJ website a comment directed to the ministry together with the official response. The comment was essentially, "The MOJ should administer a notarial exam in accordance with the Public Notary Act, opening the profession up to those in the private sector." The official response was essentially that it was desirable to have persons with government experience who would be fair and neutral, and that since any test would overlap with the NBE it would be unnecessarily duplicative to have one given that appointments are already being made out of persons who have passed the NBE and have a wealth of practical experience. This comment and response have since disappeared from the MOJ website, though the author has a printout on file.

192. Public Notice Regarding the Adoption of the Notary as Defined in Article 13 of the Notary Act, Ministry OF Justice (Nov. 6, 2013), http://www.moj.go.jp/jinji/shomu/kanbou_jinji14.html.

193. For Notary Public Offering of Article 132 Bruno Notary Law in 25 Fiscal Year, MinisTRY OF Justice (Nov. 8, 2013), http://www.moj.go.jp /MINJI/minji03_00019.html. Note that the MOJ rules also make persons having 15 or more years experience as a Gyoseishoshi lawyers or in a corporate legal department eligible to apply. Id.

194. See generally Public Notary Report, supra note 191. The Report notes that in 2003, five non-government applicants took the Article 13-2 exam but none passed, and includes a quote from the Chairman of the Federation of Public Notaries to the effect that Public notaries must be fair and have a sense of justice, in which respect "civilians" are a more worrisome prospect than someone from a court or prosecutor's office. Id. Thus here again, the testing process may function primarily to exclude applicants who are government service "outsiders." See also Tsukanshihō [Customs Brokering Act], Law No. 122 of 1967, art. xx (Japan). 
What impact might this cozy arrangement have on other aspects of the legal system? In addition to administering the Notary Act, the MOJ also has primary responsibility for the Company Act. ${ }^{195}$ Under Article 30 of that statute, the articles of incorporation of any newly established joint-stock corporation (kabushiki kaisha, the standard corporate form used to conduct most for-profit businesses) must be certified by a public notary. ${ }^{196}$ A similar requirement applies to the charter documents of foundations and various other corporate forms. Under the "Notarial Fees Ordinance" (also under the jurisdiction of the MOJ), the fee for notarizing articles of corporation is $¥ 50,000$ (approximately $\$ 500$ at current exchange rates). ${ }^{197}$

According to MOJ statistics, 80,862 newly-incorporated joint stock corporations were registered in 2012. ${ }^{198}$ Assuming each one required the notarial certification of articles of incorporation, this works out to $¥ 4.042$ billion in notarial fees. Divided equally between 500 notaries, we arrive at a mean annual income of just over $¥ 8$ million per notary from this type of incorporation alone. ${ }^{199}$ Whether the certification of articles of incorporation is meaningful for any reasons relevant to corporate law will be left to specialists in that field. For purposes of this article it is hopefully obvious that at the very least the requirement has the benefit of ensuring that a category of amakudari legal profession is suitably lucrative. Furthermore, primary responsibility for drafting the law that confers this benefit on public notaries lies

195. See Legal Jurisdiction of the Ministry of Justice, MinISTRY OF JUSTICE, http://www.moj.go.jp/hisho/shomu/syokan-horei_horitsu.html\#02 (last visited Feb. 23, 2014) (showing the Company Act listed as being under MOJ jurisdiction).

196. Kaishahō [Company Act], Law No. 86 of 2005, art. 30 (Japan).

197. Kōshōnin tesūryō rei [Cabinet Order on Notarial Fees], No. 242 of 1993, art. 35 (Japan). "For Notary System, MOJ," http://www.moj.go.jp/MINJI/minji30.html (noting that the fees charged by notaries are set by this regulation and, according to the MOJ, notaries are prohibited from charging any extra or additional fees).

198. Ministry of Justice, Corporation Registration Statistics, ESTAT.GO.JP, http://www.e-stat.go.jp/SG1/estat/List.do?lid=000001110785.

199. Needless to say, some notarial jurisdictions - Tokyo, for example are likely to have far more incorporations than others. 
with the same officials who are likely to benefit from it. ${ }^{200}$ With the mandatory retirement age for notaries set by law at 70 , persons retiring into such positions are ensured ample compensation for years after retirement from their court or ministry. ${ }^{201}$

Notarial fees also help provide insight into some of the systemic costs of amakudari. Incorporating in Japan is comparatively expensive, since there is a separate incorporation tax that is based on capitalization but starts at a minimum of $¥ 150,000{ }^{202}$ This is in addition to the $¥ 40,000$ in revenue stamps that must be affixed to the articles of incorporation (unless they are filed and certified electronically). Thus, establishing a corporation in Japan will cost around \$2,000 dollars (at current exchange rates) in government-imposed fees and taxes, not including any service provider or document preparation fees. ${ }^{203}$

200. In August 2013, the author made a formal administrative document disclosure request [gyōseibunshō kaiji seikyū] to the MOJ asking for information on aggregate notarial fees paid to all notaries in Japan: such a total would make it easy to arrive at a median per-notary income. The MOJ response was that no total information had been compiled and that while it had information on the fees received by individual notary offices, it could not disclose them because it would affect the interests of individual notaries. Email from MOJ Civil Bureau to author (Sept. 2013) (copies on file with the author). That the MOJ has information on individual notary fees but has not taken the trouble to aggregate it for statistical or policy purposes is another indicator of possible official sensitivity about the realities of the notary system.

201. See Kōshōninhō [Public Notary Law], Law No. 53 of 1908, art. 15 (Japan). The fact that a prosecutor may have spent most of his or her career in criminal court and know little or nothing about title registration does not appear relevant to their eligibility for notarial positions.

202. Tax table No.7191 registration and license tax, NAT'L TAX AGENCY, http://www.nta.go.jp/taxanswer/inshi/7191.htm (last visited Feb. 23, 2014).

203. By way of comparison, service providers offer a Singapore incorporation package for under $\$ 788$ (Singapore dollars), which includes service fees, document preparation and government fees. Services and Fees, RIKVIN, http://www.rikvin.com/services-and-fees/ (last visited Feb. 23, 2014). The State of Delaware charges a basic fee of only $\$ 89$ for incorporations. DEL. Dep't of State, Corporate Fee Schedule (Aug. 2013), available at http://corp.delaware.gov/Aug11Fee.pdf. 
As explained by the MOJ, although they are not public servants as defined in the National Public Servant Act, because they perform a public function they are considered public servants for practical purposes. This status includes being immune from negligence liability: beneficiaries of wills rendered invalid or other persons harmed due to negligence on the part of a public notary must seek recourse from the state under the State Redress Act rather than sue the notary personally for malpractice. ${ }^{204}$

One could thus look at the fees charged for certifying articles of incorporation as a form of tax. After all, they are used to compensate what is effectively a form of public servant. It is just a form of tax that never passes through the public coffers and one that only inures to the benefit of a select group of former bureaucrats. Whether it is fundamentally different from the tax that is effectively being imposed on construction companies that have to put unneeded amakudari "advisors" on their payrolls is debatable. In any case, public notaries provide a useful illustration of one way in which amakudari functions, through a law that effectively channels private funds to a specific professional group designated by a supervising ministry.

\section{G. Government Legal Professions and More Amakudari}

The status of public notaries as quasi-public servants is a useful segue into another subject that is relevant to both the subject of Japan's legal professions and amakudari. That subject is the distinct legal professions that exist only within the government.

204. Notary Public's Office and the First Notary Public, Ministry oF JUSTICE, http://www.moj.go.jp/MINJI/minji30.html (last visited Feb. 25, 2014). The freedom of public notaries from personal liability for their own negligence was confirmed in a 1957 case in the Tokyo District Court. Tokyo District Court, Apr. 20, 1957, 8 Kakyūmin 807. It is unclear whether any of the judges involved in deciding the case went on to become public notaries after retirement. 
Just as in other countries, a great deal of law-related work is performed within Japanese governmental agencies at national, prefectural and municipal levels and in all three branches of government. In the United States, such tasks are likely to be performed by qualified attorneys, starting with the judicial clerkships to which many US law students aspire. In Japan, many people engaged in such tasks may be doing so with nothing more than an undergraduate degree in law (if that). ${ }^{205}$

Yet there are also public service legal professions that are identifiable by a specific title and qualification regime, frequently a combination of testing and training. While the list is likely subject to expansion, it would at the very least include: Court Administrator (saibanshojimukan), Family Court Investigators ${ }^{206}$ (kateisaibansho chosakan) and judicial clerks (saibansho shokikan), as well as vice-prosecutors (fukukenji) and a variety of MOJ administrators (homujimukan, homushō senmonnshokuin). The persons performing these roles may acquire a high level of legal knowledge, at least with respect to courtroom and related procedures. For example, Family Court Investigators are sometimes said to have a level of legal knowledge at least comparable to assistant judges, and judicial clerks prepare documents, conduct legal research, manage the court's documents and may issue dispositive documents such as orders to pay or enforcement notices. ${ }^{207}$

These types of personnel are subject to the same retirement age as applies to other public servants: 60 (subject now to reemployment until 65). The procurement of post-retirement jobs

205. The same is true of Japanese corporate legal departments, which are likely to be staffed primarily with persons having no more formal qualifications than an LL.B. from a Japanese university, if that.

206. "Investigator" is the closest English translation. In the Japanese courts' English website these personnel are referred to as "probation officers," possibly because of their involvement in the juvenile criminal proceedings, which are conducted in family courts.

207. Saibansho hō [Court Act], Act No. 59 of 1947, art. 60 (Japan); see also Court Clerk, COURTS IN JAPAN, http://www.courts.go.jp/saiyo/message/ syokikan/ (last visited Feb. 25, 2014) (further describing the role of court clerks). 
for these personnel also appears to influence the way that certain categories of jobs are allocated, particularly those within the judicial system.

\section{Summary Court Judges.}

Take summary court judgeships, for example. In the United States, serving as a small-claims court judge might well serve as a starting point for a young American trial lawyer hoping to use the position as a stepping stone to a more significant role on the bench. By contrast, judgeships at Japanese summary courts (the lowest rung of the judicial system) are more likely to be older and ex-public servants.

Appointments of judges to inferior courts are effectively made by the Supreme Court's secretariat. ${ }^{208}$ Under the Courts Organization Act, summary court judges may be appointed not only from the ranks of judges, lawyers and prosecutors who have passed the NBE, but from a wide range of non-judicial court and non-prosecutorial MOJ personnel as well. ${ }^{209}$ Appointments are also possible from a broadly defined category of "other persons with suitable experience and knowledge" category. ${ }^{210}$ As a result,

\footnotetext{
208. Nihonkoku Kenpō [Kenpō] [CONStitution], art. 80, para. 1 (Japan).

209. Saibanshō hō [Court Act], Act No. 59 of 1947, art. 44 (Japan)

210. Id. art. 45. The appointment process for summary court judges is more complicated, with a Supreme Court committee comprised of judges, prosecutors, lawyers and others making appointment decisions for candidates being appointed through the "otherwise qualified" category in Article 45, and each District Court having a summary court judge nominating committee comprised of the chief judge of the court, other judges, a prosecutor, lawyers and persons of learning, who recommend candidates for judgeships within their jurisdiction to the Supreme Court's nominating committee. Kan'i saibanshō hanji senkō kisoku [Summary court judge selection rules], Supreme Court rule No. 2 of 1947; see also KAN'I SAIBANSHŌ HANJI SENKŌ TETUZUKI NI TSUITE [REGARDING THE PROCESS OF APPOINTING SUMMARY COURT JUDGES], available at http://www.kantei.go.jp/jp/singi/sihou/kentoukai/seido/dai12/12siryou22.pdf (discussing the process of appointing summary court judges; according to this document a test is also involved, but parts of it may be waived, and there have been allegations of impropriety in the testing process to ensure that only the "right" people pass it). See also Noriyuki Imanishi \& Aki Komiyama,
} 
summary court judges are likely to be former court administrators who have amassed decades of experience in court practice and procedures.

Although writing of a time several decades past, court clerk turned summary court judge Shuhei Baba's description of the appointment process after the introduction of the qualifying exam for summary court judges is worth quoting at length. Not only does it illustrate the realities of the summary court judge appointment process, but it has troubling implications about how amakudari may affect the objectivity of the qualifying exams used to control entry into at least some of the legal professions.

Court clerks and others who had been studying for the $\mathrm{NBE}^{211}$ flocked to take the exam, which became very competitive as a result. Separate from these people, there were executive directors [jimukyokuchō] of high courts, district and family courts, chief clerks and other managerial personnel who are recommended [for summary court judgeships] and for whom the written law portion of the exam is waived; about 15 to 20 of these people are appointed as summary court judges every year. Within the courts, the former are called the shikengumi [i.e, those who applied to become judges by sitting for and passing the exam] and the latter the suisengumi [those who

Saibankan no "uraguchi" ninkan, "amakudari" wo kokuhatsu [Amakudari exposed! Back-door judicial appointments], in SHUKan Asahi 36-37 (Mar. 2007) (alleging that the summary court examination process was rigged, with "preferred" candidates being excused from the written portion of the exam and the subject matter of the oral section being leaked to them in advance). "Preferred" candidates were supposedly those who had risen to the highest level of administrative posts, such as chief clerk or chief of the secretariat of a court. The article quotes an unidentified summary court judge who obtained his post through this route: "The courts have their own slush funds [uragane] and scandals that they don't want the people to know about. Can judges who spend all their time writing judgments take care of this? Those of us in the administrative posts are the ones who have to get dirty [yogoreyaku]. What is wrong with us having an amakudari reward?"

211. Administrative positions in the court system were (and still are) one possible destination for persons unsuccessful in passing the NBE, and some might continue attempting to pass the exam while working at the court. 
were recommended as candidates for appointment by judicial administrators]. ${ }^{212}$

Noting that the suisengumi had less legal knowledge but were more likely than shikengumi judges to be paid more, advance up the pay scale more quickly and be posted to better courts (i.e., in big cities), ${ }^{213}$ Baba describes how the remaining portion of the qualifying exam was "fixed" for them:

When they were younger the suisengumi were involved in trial practice, but having since worked in administration for a long time, many had knowledge of basic law and trial practice that was not great when compared to the shikengumi; there is an undeniably big difference in ability between them and the shikengumi. The written portion of the test is waived for the suisengumi. They still have to "pass" the oral part of the exam, but none of them has ever failed the oral exam. The members of the suisengumi "pass" the oral portion because before the test the executive director of the high court tells them "for the civil portion come prepared by reading this, for the criminal portion read that": he forewarns them what the questions will be about. ${ }^{214}$

As to the reasons for this odd form of discrimination, Baba speculates:

Why would the Supreme Court treat suisengumi judges better than shikengumi judges, despite the former having inferior courtroom abilities? The answer is simple. There are two likely reasons:

1. The suisengumi had the opportunity to be appointed as summary court judges earlier in their careers but did not do so. Instead they devoted themselves to working in the court administration (although many may have simply given up

212. ShuHEI BABA, SAIBANSho DE MitA Koto KitTA Koto [Things I SAW AND HEARD AT COURT] 45-46 (1999) (Japan).

213. Id. at 47-50.

214. Id. at 47. 
after sitting for the exam may times and failing) and serving the chief judges of the high, district and family courts who as a result feel an affection for them and want to see them rewarded.

2. If suisengumi members who were executive directors or chief clerks are not treated well, top administrative employees will leave to become summary court judges mid-career, leaving no competent workers to assist with judicial administration. So it is necessary to treat suisengumi preferentially in order to show general employees that they can stay in general administrative positions and that even if they finish in such a position they will not lose out." ${ }^{215}$

The reasons articulated for reserving certain judgeships for retiring administrative personnel may well make sense. Of course this means that such opportunities are necessarily denied to potentially qualified (and younger) candidates from outside the judiciary.

\section{Other Court Personnel.}

The court system also utilizes a variety of other types of specialized personnel, often in a part time capacity. These include family court mediators (kajichōtei'in), civil mediators (minjichōtei'in), court enforcement officers (shikkōkansometimes also referred to as "bailiffs" in English literature) and various other roles. These roles have either a higher retirement age or (apparently) no formal retirement age at all. ${ }^{216}$

Against this background, reports on the re-employment of non-judicial court personnel makes interesting reading. The two most recent reports are dated of December 2011 and 2012 respectively and give details as to the court employees who have

215. Id. at 50-51.

216. Mini chotei'in oyobi kajichotei'in kisōku [Civil mediator and family mediator rules], Sup. Ct. Rule no. 5 of 1973, art. 1 (Japan). 
been re-employed after or before reaching retirement age. ${ }^{217}$ Many elected to remain in public service in a similar role, which is now possible up to the age of $65 .{ }^{218}$ A surprising number of such employees - generally judicial clerks (shokikan) go on to become summary court judges, with others becoming family court mediators together with a smattering of court enforcement officers and notaries. Virtually all personnel reported left court service at the age of 60 or in their late 50's.

\begin{tabular}{|l|c|c|}
\hline Year: & $\mathbf{2 0 1 1}$ & $\mathbf{2 0 1 2}$ \\
\hline $\begin{array}{l}\text { Total instances of } \\
\text { re-employment reported }{ }^{219}\end{array}$ & 70 & 64 \\
\hline Continue in same or similar role & 13 & 14 \\
\hline Summary court judge & 19 & 15 \\
\hline Family Court Mediator & 16 & 19 \\
\hline Civil Mediator & 10 & 5 \\
\hline
\end{tabular}

217. See generally SAIBANKAN OYOBI SAIBANKAN NO HISHOKAN IGAI NO SAIBANSHŌ SHOKUIN NO TAISHOKUKANRI NI KANSURU KISOKU DAI 30 JO NI MOTODUZUKU SAIBANNKAN OYOBI SAIBANNKANN NO SAIBANNSHŌ SHOKUIN NO SAISHUSHOKU JOKYŌ NO KOHYŌ [PUBLICATION OF STATUS OF RE-EMPLOYMENT OF COURT PERSONNEL OTHER THAN JUDGES AND JUDICIAL SECRETARIES PURSUANT to ARticle 30 of the Rules Relating to the Management of Retirement OF Court EMPloyees other than Judges AND Judicial Clerks (Dec. 2011), available at http://www.courts.go.jp/vems_lf/20564003.pdf; SAIBANKAN OYOBI SAIBANKAN NO HISHOKAN IGAI NO SAIBANSHO SHOKUIN NO TAISHOKUKANRI NI KANSURU KISOKU DAI 30 JO NI MOTODUZUKU SAIBANNKAN OYOBI SAIBANNKANN NO SAIBANNSHŌ SHOKUIN NO SAISHUSHOKU JOKYŌ NO KOHYŌ [PUBLICATION OF STATUS OF RE-EMPLOYMENT OF COURT PERSONNEL OTHER THAN JUDGES AND JUDICIAL SECRETARIES PURSUANT TO ARTICLE 30 OF THE RULES RELATING TO the Management of Retirement of Court Employees other than Judges AND JUDICIAL CLERKS (Dec. 2012), available at http://www.courts.go.jp/ vcms_lf/H23_saisyuusyoku_jyoukyou.pdf.

218. Such re-employment involves lower benefits and status with no prospect of promotion. Thus, instances of court of employees being directly reemployed show them moving to the same sort of role as before "retirement" but at a lower level, for example going from being Chief Investigator or Head Clerk at a particular court to a being a plain investigator or court at a different court.

219. Because some of the roles (family court mediator, for example) are not full time, data for both years includes a small number of instances of the same person being reported twice (by becoming both a family court mediator and a civil mediator, for example). 


\begin{tabular}{|c|c|c|}
\hline Year: & 2011 & 2012 \\
\hline Foundation 220 & 4 & 2 \\
\hline Public Notary & 2 & 2 \\
\hline Court Enforcement Officer & 3 & 2 \\
\hline Other & 4 & 5 \\
\hline
\end{tabular}

Of course this information only represents a snapshot of applicable ex-court employees approaching mandatory retirement age in the years given. Unfortunately, specific information is not available on the background of particular types of court roles, leaving the researcher to rely on a combination of anecdotal evidence ${ }^{221}$ and such snapshots. ${ }^{22}$

We can also obtain a similar snapshot of prosecutorial and MOJ officials "retiring" into other government legal jobs; doing

220. Foundations into which court employees retire include Japan Legal Support Center, which effectively functions as the national legal aid system, the Hōsō Kyōkai, a foundation related to the legal profession, and the Justice Association of Japan (shihōkyōkai -JAJ). See Main Page, Justice Ass'N OF JAPAN, http://www.jaj.or.jp/ (last visited Mar. 31, 2014), for more information. An interesting example of amakudari relating to this last institution was the Head Clerk of the Criminal Division of the Tokyo High Court who retired at the age of 60 in 2010 to become the head of the JAJ's copy department. The JAJ was one of the few legal system foundations subject to the scrutiny of the jigyōshiwake process, which revealed that 4 of its 11 directors (including both full time directors) and 102 of 133 employees were former government employees. Among other things the JAJ provides copy services to court users, at the rate of $¥ 20$ /page for self-service and $¥ 50$ /page when performed by JAJ employees, rates which the evaluators found to be excessive. Evaluators also questioned why JAJ had enjoyed a monopoly on such services for so long, and suggested that "Based on the current conditions, it appears that the main purpose of the business is to take care of court OB." EVALUATION REPORT ON JigYo SHIWAKE, supra note 51, at 124-26.

221. See Enforcement Officer, WIKIPEDIA, http://ja.wikipedia.org/wiki /\%E5\%9F\%B7\%E8\%A1\%8C\%E5\%AE\%98 (last visited Mar. 31, 2014); Court Clerk, WIKIPEDIA, http://ja.wikipedia.org/wiki/\%E8\%A3\%81\%E5\%88\% A4\%E6\%89\%80\%E6\%9B\%B8\%E8\%A8\%98\%E5\%AE\%98 (last visited Mar. 31,2014 ) (asserting that by passing additional tests they can become court enforcement officers, summary court judges or assistant prosecutors).

222. Supreme Court response to author's request for information requesting the breakdown of the backgrounds of summary court judges (August 2013) (on file with author) (stating that no document with breakdown of the backgrounds of summary court judges existed). 
so requires an examination of a different set of reports, as it involves employees of the executive branch rather than the judicial. That list is the "Public Disclosure of re-employment of national public servants, pursuant to Article 106-25(2), etc. of the National Public Service Act ," published jointly by the Cabinet Secretariat and the MIC, which has concurrent jurisdiction with the National Personnel Agency over the public service. ${ }^{223}$ The 2012 list covers 133 cases of prosecutors and other MOJ officials retiring and being re-employed during the March 2010-April 2011 period. ${ }^{224}$ In the interests of space, only the highlights will be given, but it includes details about 35 prosecutors and officials becoming public notaries (with an additional three assuming other roles within notarial offices), fourteen becoming family court or civil mediators, and one who was appointed a summary court judge. With respect to the legal professions, one registered as a gyōseishoshi lawyer and two as administrative scriveners. ${ }^{225}$ One also became a full time director (senmu riji) at the Federation of Land and Building Investigators.

223. See generally KOKKA KŌMUIN HŌ DAI 106 NO 25 JŌ 2KŌ TŌ NO KITEI NI MOTOZUKU KOKKA KŌMUIN NO SAISHŪSHOKU JŌKYŌ NO KŌHYŌ NIT SUITE [Regarding the publication of the situation of reemployment of national public servants in accordance with the provisions of Article 106-25(2), etc. of the National Public Service Act] 2012 (describing retirement patterns of Japanese prosecutors and employees of the Ministry of Justice), available at http://www.cas.go.jp/jp/houdou/pdf/120907_1dokuhou.pdf.

224. Id.

225. Seventeen - presumably all former prosecutors - also became lawyers. Those who entered other legal professions would have been other prosecutorial or MOJ employees who had not passed the NBE. Top prosecutors also seemed to do well in the private sector, with one former supreme prosecutor becoming an advisor at Nomura Securities, and another picking up board positions at two separate companies (Daiwa Securities and an advertising company). Although many on this list retired at or close to the age of 60 , the age range was wider than on the list of court employees discussed above, including a number of people leaving government service in their thirties and forties. Former prosecutors becoming lawyers accounted for a significant portion of these younger retirements. Id. 
A large number were also reemployed as public servants by prosecutorial offices and correctional institutions. ${ }^{226}$

\section{CONCLUDING REMARKS - AMAKUDARI AS A STRUCTURAL PROBLEM IN THE LEGAL SYSTEM AND BEYOND}

So what?

There may be nothing wrong with court clerks becoming summary court judges, MOJ officials becoming family court mediators, or retiring bureaucrats of one type or another becoming directors at foundations or registering as licensed providers of legal services. In many cases there can be little doubt that they bring useful skills, experience, and connections from their former government employment to their new roles.

In fact there may well be "good" amakudari as well as "bad," and this article has not sought to distinguish between the two or to justify or criticize the institution in any particular context. Whether any of the particular modes of legal system amakudari serve a useful purpose, are merely forms of institutionalized corruption or can be evaluated in other more nuanced terms, are subjects that will be left to more focused research by other scholars.

The primary purpose of this article has been simply to point out that amakudari exists as an endemic feature of the Japanese legal system, one that may exercise a myriad of subtle influences on the way the system is designed and operated. It may also be a feature of the system that is rarely remarked upon openly, possibly because there is little benefit to most people actively involved in the legal system to bringing attention to the practice. Furthermore, comment may be further stifled by cognizance of the reality that insofar as it involves the creation of official or unofficial systems of preferential access to employment opportunities for ex-officials, amakudari is likely to seem contrary to some of the basic principles that people expect the legal system to uphold. Finally, researching the subject

226. Another interesting career transition was the warden of a juvenile detention facility who retired to became the principal of a nursery school! Id. 
systematically may be difficult because on a very basic level there is a public, not to mention political, perception that it should not happen at all and that government institutions, which create and perpetuate amakudari systems - through law and regulation - control most of the information yet have little to gain from making it readily accessible.

Having brought the issue to the attention of readers, the author will only offer three closing observations on the subject. The first is that the prevalence of amakudari and other government involvement in the legal profession (broadly defined) and public-interest foundations and institutions is likely a factor that makes the Japanese legal system as a whole seem to function in a much more "pro-government" fashion than might be the case in countries such as the United States. ${ }^{227}$

The second is that, as suggested by the dynamics underlying the appointment of summary court judges described above, at least some types of amakudari may reward what I will call "internal service" (administering the relevant institution in

227. According to its English website, the goal of the CHRET is "to contribute to the protection of fundamental human rights through comprehensive education, awareness-raising and public information regarding human rights; research, surveys, data gathering/provision and international partnerships on human rights; and consultations on human rights issues." Objective, CENTER FOR HuM. RTS. AFFs. (2011), http://www.jinken.or.jp/en/ objective. Yet in its description of the types of human rights issues facing Japan today (only available on the Japanese version of the site), virtually every "human rights" issue it identifies is some sort of discrimination (discrimination against people with AIDS/HIV, elders, non-Japanese people, ex-cons, women, etc.). While these may indeed be problems worth addressing, any discussion of what are traditionally associated with human rights violations - unlawful detention and torture, for example - is completely missing. This is only natural, perhaps, given that the MOJ to which the foundation is beholden is responsible for the criminal justice system, the immigration detention system and all aspects of the correctional system, where most "traditional" human rights violations are likely to occur. Guide, CENTER FOR Hum. RTS. AFFs. (2011), http://www.jinken.or.jp/jinken-info/jinken-guide. The foundation also has a site for children which explains human rights in similar terms, illustrating how such institutions can potentially play a role in forming the "rights consciousness" or "legal consciousness" of the Japanese people. Children's Site, CENTER FOR HuM. RTS. AFFS. (2011), http://www.jinken.or.jp/jinken-info/daiboken-intro. 
accordance with the needs of its members) over "external service" (providing the public outside the institution with the best possible service, perhaps just "public service").

The third is that whether good or bad, any type of amakudari system involves reserving certain economic opportunities for the benefit of people above a certain age. A corollary of this obvious conclusion is that it is a system that necessarily disadvantages younger people. Whether it is in the public interest non-profit sector, entrepreneurship, or pursuing a particular profession, amakudari would seem to either overtly or at least passively limit the opportunities available to new entrants, most of whom could be expected to be younger than ministry OBs approaching retirement age.

For example, providing photocopy services to court patrons would seem an obvious area for cost-savings through competitive bidding from the private sector, an area in which new entrants could seek a competitive advantage through new technology or business models. Actually making the photocopies is the sort of low-skilled labor that could be done by new, young entrants to the labor market. In Japan these opportunities are reserved to ex-court employees. Similarly, as already noted, acting as a small claims court judge or petty criminal magistrate might be an educational entry-level job for young lawyers aspiring to a judicial career. Yet in Japan such positions are reserved for court employees at the end of their public service career.

Looked at in this light, the various exams for the legal professions discussed in this article can be seen not so much as "qualifying" exams, but as a medium for limiting new entrants from outside the sphere of governments, entrants who are most likely to be younger people - while leaving them open to exofficials in their fifties and sixties. ${ }^{228}$

228. For example, of the 59,948 people who sat for the administrative scrivener exam in 2012, 48,788 were in their forties or younger. See Test Results Analysis Data, Found. Admin. Scrivener Test Research Ctr. (Nov. 10, 2009), http://gyosei-shiken.or.jp/bunseki/. 
Bengoshi lawyers are not an amakudari profession in the same way, since the only people who can retire into the profession are judges and prosecutors who are already qualified to practice as lawyers because they have passed the NBE. Nonetheless, the NBE still provides a similar function, only it limits the number of younger entrants to the one legal profession that does not have an amakudari backdoor rendering it beholden to a ministry. ${ }^{229}$

In July of 2004 - shortly after most of Japan's new law schools had opened their doors to students - representatives of the Supreme Court and the MOJ appeared before a study group of the government's Justice Reform Council. Both were there to make their case for retired summary court judges and viceprosecutors to be granted a "quasi-lawyer" (junbengoshi) qualification that would allow them to practice before the nation's summary courts. ${ }^{230}$ These proposals were not adopted, and Japan's lawyers have been understandably opposed to recognition of such a qualification. ${ }^{231}$

Coming as they did just two years before law school students started to graduate (the first classes did so in 2006), a time when it would have been (or at least should have been) utterly

229. A few years ago the author participated in a meeting where a senior MOJ official was asked point blank whether the NBE was a "qualifying exam" (shikaku shaken) or a "selection exam" (senbatsu shaken). He confirmed that it was a "qualifying exam." He was then asked whether that meant that in theory everyone who sat for the exam could pass it if they all achieved the required score. He confirmed that was possible - in theory. Less than ten minutes later he was discussing what the "correct number" of passers might be, nicely illustrating the reality that it in reality is a "selection exam" intended to generate a largely predetermined number of passers.

230. Hōsō seido kentōkai [Summary minutes of $25^{\text {th }}$ session of Legal Profession Committee], (July 1, 2004), available at http:/www.kantei.go.jp/jp/ singi/sihou/kentoukai/seido/dai25/25gaiyou.html. Recall from the discussion above that summary court judges are unlikely to have passed the bar exam and are thus not eligible to register as bengoshi. See supra Part V.B.1.

231. See Statement of Objection, DAIICHI TOKYO BAR Ass'N (2006), http://www.ichiben.or.jp/approach/opinion/opinion2006/post-9.html; Statement of Objection, Yоконама BAR Ass'N (2002), http://www.yokoben.or.jp/ profile/gaiyou/statement/2002/post-21.html. 
predictable to legal system insiders that the sudden growth in bengoshi lawyer population would become a "problem," the request seems particularly galling - at least to someone like the author who has spent close to a decade watching the NBE regime inflict unnecessary suffering on young law students and graduates.

At the time of writing a legal restriction limited law school graduates (or passers of the equivalency exam) to sitting only three times during the five years after graduation. ${ }^{232}$ In 2013, the NBE had a pass rate of $26.8 \%$ and saw 1,334 takers "strike out"i.e. fail for the third time, rendering them ineligible to try again. ${ }^{233}$ So while hopeful young new prospective entrants see their efforts frustrated in this way - in part because there are supposedly too many in the profession already - as far as the MOJ and the judiciary are concerned, any increase in the number of legal professionals who are in their sixties, overwhelmingly male and well-acclimated to the workings of judicial bureaucracies is apparently acceptable.

232. Shihōshikenhō [National Bar Exam Act], Law No. 140 of 1949, art. 4 (Japan), On March 4, 2014 the cabinet passed a resolution approving a proposed amendment that would allow a person to sit for the exam five times during the five year period after graduation. Shihōshiken "gonen de gokai" ni juken seigen kanwa kaiseian wo kakugi kettei [Limits on sitting for National Bar Exam to be relaxed to "five times in five years" - cabinet resolution approves proposed amendment], SANKEI SHINBUN OnLINE, http://sankei.jp.msn.com/politics/news/140304/plc14030412070016-n1.htm (last visited Mar. 4, 2014).

233. Shihoshiken no gokaku 2049 nin, 53 nin gen, nao teimei [2,049 people pass the bar exam, 53 less [than last year], still struggling], THE CHugoku Shinbun ONLINE (Sept. 10, 2013) http://www.chugokunp.co.jp/News/Sp201309100136.html. The three strikes rule was supposed to encourage unsuccessful takers to move on with their lives, though technically they can try again by trying to pass the law school equivalency exam (yobishiken), which had a pass rate of approximately 2013 but which qualifies the passer to sit for the NBE three times without graduating from law school. "Three-strikers" can also apparently become eligible for another three attempts by graduating from law school a second time; how to handle applications from graduates of other law schools is an issue that at least some law school administrators have had to develop a policy on. 
As the above vignette shows, amakudari involves persistent efforts by government actors to reserve employment and other economic opportunities for a select body of older members of Japanese society by correspondingly limiting the opportunities available to new entrants, who will invariably be younger. As this article has tried to illustrate, amakudari is a structural problem in the legal system, part of its "hidden fabric" as much as it is in the Japanese economy. Given Japan's growing demographic imbalance, with the elderly poised to outnumber the young, many of whom are struggling to find jobs, get married and raise a family in the face of declining lifetime employment in the private sector after two "lost decades," perhaps it is a structural issue worthy of greater attention. 
